\title{
Scaling relations for large Martian valleys
}

\author{
Sanjoy M. Som, ${ }^{1,2}$ David R. Montgomery, ${ }^{1,2}$ and Harvey M. Greenberg ${ }^{1}$ \\ Received 27 February 2008; revised 22 October 2008; accepted 11 November 2008; published 19 February 2009.
}

[1] The dendritic morphology of Martian valley networks, particularly in the Noachian highlands, has long been argued to imply a warmer, wetter early Martian climate, but the character and extent of this period remains controversial. We analyzed scaling relations for the 10 large valley systems incised in terrain of various ages, resolvable using the Mars Orbiter Laser Altimeter (MOLA) and the Thermal Emission Imaging System (THEMIS). Four of the valleys originate in point sources with negligible contributions from tributaries, three are very poorly dissected with a few large tributaries separated by long uninterrupted trunks, and three exhibit the dendritic, branching morphology typical of terrestrial channel networks. We generated width-area and slope-area relationships for each because these relations are identified as either theoretically predicted or robust terrestrial empiricisms for graded precipitation-fed, perennial channels. We also generated distance-area relationships (Hack's law) because they similarly represent robust characteristics of terrestrial channels (whether perennial or ephemeral). We find that the studied Martian valleys, even the dendritic ones, do not satisfy those empiricisms. On Mars, the width-area scaling exponent $b$ of $-0.7-4.7$ contrasts with values of $0.3-0.6$ typical of terrestrial channels; the slope-area scaling exponent $\theta$ ranges from $-25.6-5.5$, whereas values of $0.3-0.5$ are typical on Earth; the length-area, or Hack's exponent $n$ ranges from 0.47 to 19.2, while values of $0.5-0.6$ are found on Earth. None of the valleys analyzed satisfy all three relations typical of terrestrial perennial channels. As such, our analysis supports the hypotheses that ephemeral and/or immature channel morphologies provide the closest terrestrial analogs to the dendritic networks on Mars, and point source discharges provide terrestrial analogs best suited to describe the other large Martian valleys.

Citation: Som, S. M., D. R. Montgomery, and H. M. Greenberg (2009), Scaling relations for large Martian valleys, J. Geophys. Res., 114, E02005, doi:10.1029/2008JE003132.

\section{Introduction}

[2] The surface of Mars preserves striking evidence for aqueous activity in incised valley networks and outflow channels. Although it is generally agreed upon that the major outflow channels such as Ares Vallis, Kasei Valles, and Ravi Vallis (among others) were formed by catastrophic release from a liquid water aquifer [Carr, 1996], the formation of Martian valley networks remains controversial [Ansan and Mangold, 2006; Carr, 1995; Gulick, 2001; Malin and Carr, 1999; Mangold et al., 2004; Sharp and Malin, 1975]. Indeed, their wide range of morphologies has motivated a broad range of hypothesized formation mechanisms, the most commonly cited of which are meteoric water in a warm-wet environment [e.g., Ansan and Mangold, 2006; Craddock and Howard, 2002; Howard et al., 2005; Hynek and Phillips, 2003; Irwin et al.,

\footnotetext{
${ }^{1}$ Quaternary Research Center, Department of Earth and Space Sciences, University of Washington, Seattle, Washington, USA.

${ }^{2}$ Astrobiology Program, University of Washington, Seattle, Washington, USA.

Copyright 2009 by the American Geophysical Union. 0148-0227/09/2008JE003132\$09.00
}

2005b; Mangold and Ansan, 2006; Mangold et al., 2004; Sagan et al., 1973], groundwater sapping [Baker et al., 1992; Malin and Edgett, 2000; Pieri, 1980], precipitation-recharged groundwater sapping [Baker and Partridge, 1986; Luo, 2002], ground-ice melting caused by igneous intrusions [Wilhelms and Baldwin, 1989], hydrothermal hot spots of diverse origins [Brakenridge et al., 1985; Gulick, 2001; Gulick and Baker, 1989; Harrison and Grimm, 2005], basal melting of snow and ice deposits [Carr and Head, 2003; Gulick et al., 1997], mass wasting of waterlubricated flows [Carr, 1995], and degassing of $\mathrm{CO}_{2}$ clathrate [Hoffman, 2000]. Coleman [2003] argued that the fluid was likely liquid water, but major areas of outstanding debate focus on two questions: (1) was the discharge that created Martian channels of sufficient duration for them to reach grade (a graded longitudinal profile is one adjusted to transport the load supplied by the drainage area [Mackin, 1948]), and (2) was incision fed by subsurface discharge sources, or by precipitation across a drainage basin.

[3] Previous workers have used the morphometry of Martian valleys to draw inferences about their environment of formation. For example, Bhattacharya et al. [2005] present several discrete geomorphic characteristics, such as meanders and alluvial fans, as evidence for perennial 
aqueous activity on Mars. However, such evidence is very localized and the duration implied remains cryptic [Kraal et al., 2008].

[4] On the basis of studying the topography of two large drainage systems (Ma'adim Vallis and Al-Qahira Vallis), Aharonson et al. [2002] find that no significant landscape change resulted from fluvial incision, other than that directly resulting from carving of valleys. In contrast, the observation that some Martian valley networks satisfy Horton's laws [Horton, 1945] (scaling relationships based on stream ordering, bifurcation ratio, length ratio, and area ratio) has been used together with hypsometry [Ansan and Mangold, 2006] and the assumption that high drainage densities implied a warmer and wetter climate [e.g., Luo and Stepinski, 2006] to assert causative parallels between Martian valley networks and terrestrial fluvial valley networks [Ansan and Mangold, 2006; Quantin et al., 2005]. However, as cautioned by Kirchner [1993] and Carr [1995] in discussing their applicability to Earth and Mars, respectively, dendritic networks can exhibit Hortonian properties, regardless of (1) the origin of the water (e.g., precipitation across a drainage area or point sources at springs), or (2) whether flow is perennial or ephemeral. Furthermore, as particular drainage densities can be found in a wide range of climates on Earth, and are a function of climate, vegetation, relief, rock type, and time [Baker and Partridge, 1986], as well as map scale or image resolution [Carr and Chuang, 1997; Mangold et al., 2004], it could be misleading to elevate drainage density over other potential Martian climate indicators on the basis of terrestrial analogy [Carr, 1995; Carr and Chuang, 1997].

[5] Other workers have used statistical properties of Martian valley networks to infer climatic regimes that may have existed during their formation. For example, Stepinski and Stepinski [2005] and Stepinski et al. [2004] analyzed drainage networks on Earth and Mars using fractal analysis, and concluded that an arid terrestrial environment provides the best analog for the Martian valley networks. Luo [2002] used hypsometry to conclude that the form of Martian networks is consistent with formation by precipitation-recharged groundwater sapping in a warm and wet past, while Ansan and Mangold [2006] used hypsometry to suggest that Warrego Valles is "in agreement with Davis" maturity stage," implying a long period of incision during which river profiles would have evolved to achieve grade.

[6] Additionally, Irwin et al. [2005a] report that Martian valley networks in the Noachian highland are physiographically "immature." They compiled 15 channel widths (and corresponding drainage areas) incised within 15 different valleys and obtained a composite width-area scaling exponent $b$ of 0.27 . They additionally report inferred discharge and runoff production based on a relationship between discharge and width as measured in alluvial channels of the Missouri River basin (scaled for Mars). While their study represents an initial assessment of the hydraulic geometry of Martian channels, to our knowledge no systematic study of the downstream hydraulic geometry of a Martian valley network has been performed.

[7] Here, we evaluate the applicability of well established, physical relationships of terrestrial fluvial morphology to those large Martian valleys resolvable by Mars Orbiter Laser Altimeter (MOLA) topographic data [Zuber et al., 1992], which excludes from analyses finer-scale valley networks that may not be genetically similar. In order to capture as much morphological diversity as possible, we have chosen three valleys that are well dissected and approach the dendritic morphology of terrestrial channel networks (Evros Vallis, Naktong Vallis, and Indus Vallis), three valleys that are very poorly dissected with a few large tributaries separated by long uninterrupted trunks (the 2 branches of Nanedi Valles, and Nirgal Vallis), and four valleys that have negligible contributions from tributaries (Bahram Vallis, Scamander Vallis, Hrad Vallis, and Tinto Vallis).

[8] We compare their downstream variation in width with the analogous downstream variation for channels carved by perennial and ephemeral flow on Earth, as well as with catastrophic flood channels preserved in the terrestrial geological record. We further evaluate the robust terrestrial empiricisms of longitudinal profile concavity [e.g., Sinha and Parker, 1996; Whipple and Tucker, 1999] and Hack's law [e.g., Hack, 1957; Montgomery and Dietrich, 1992]. At present, the resolution of the global DEM from MOLA [Som et al., 2008; Zuber et al., 1992] precludes analysis of smaller more branched valley networks reported in the literature [e.g., Mangold et al., 2004].

[9] A key source of uncertainty in regard to the morphometric analysis of large Martian valleys is the relationship of the valleys to the flows that carved them. Indeed, Martian valleys are heavily infilled with eolian and volcanic materials, obscuring any evidence of fluvial bed forms. As such, Martian valleys that contain identifiable inner channels are extremely rare [Carr and Malin, 2000; Irwin et al., 2005a; Jaumann et al., 2005], whereas valleys with no clearly defined, inner channel are much more common. As such, pending discovery of additional channels inset within Martian valleys, a proxy for channel width is required to enable this study in comparative planetology. Since influences of secondary modification such as mass wasting, eolian processes and mantling by lava flows [Mars Channel Working Group, 1983] appear to be small in Martian valleys [Harrison and Grimm, 2005; Williams and Phillips, 2001], and many of the valleys studied here have crisp valley boundaries (see section 4), valley width becomes a plausible surrogate candidate for channel width. In any case, widening of valley widths due to hillslope erosion will more significantly affect the absolute dimension of measured valley widths, than their downstream trend, as studied here.

[10] Furthermore, noting that (1) it is often unclear that valleys do not represent channels, (2) valley width has been shown, in cases where the valley walls are not heavily dissected (akin to Mars), to be a proxy for channel width [Salisbury et al., 1968], and (3) valley width has been applied successfully in scaling laws involving channel width [Snyder and Kammer, 2008], we adopt valley width as a surrogate for channel width. In addition, downstream bed curvature (the derivative of slope) is seen as a robust fluvial parameter for geomorphic studies on Mars.

[11] The assumption that the channel-forming discharge originates from meteoric precipitation across a topographically defined drainage area underlies a hydraulic comparison between perennial channels on Earth and valley networks on Mars. Although groundwater originating from beyond the boundaries of drainage basins could contribute 


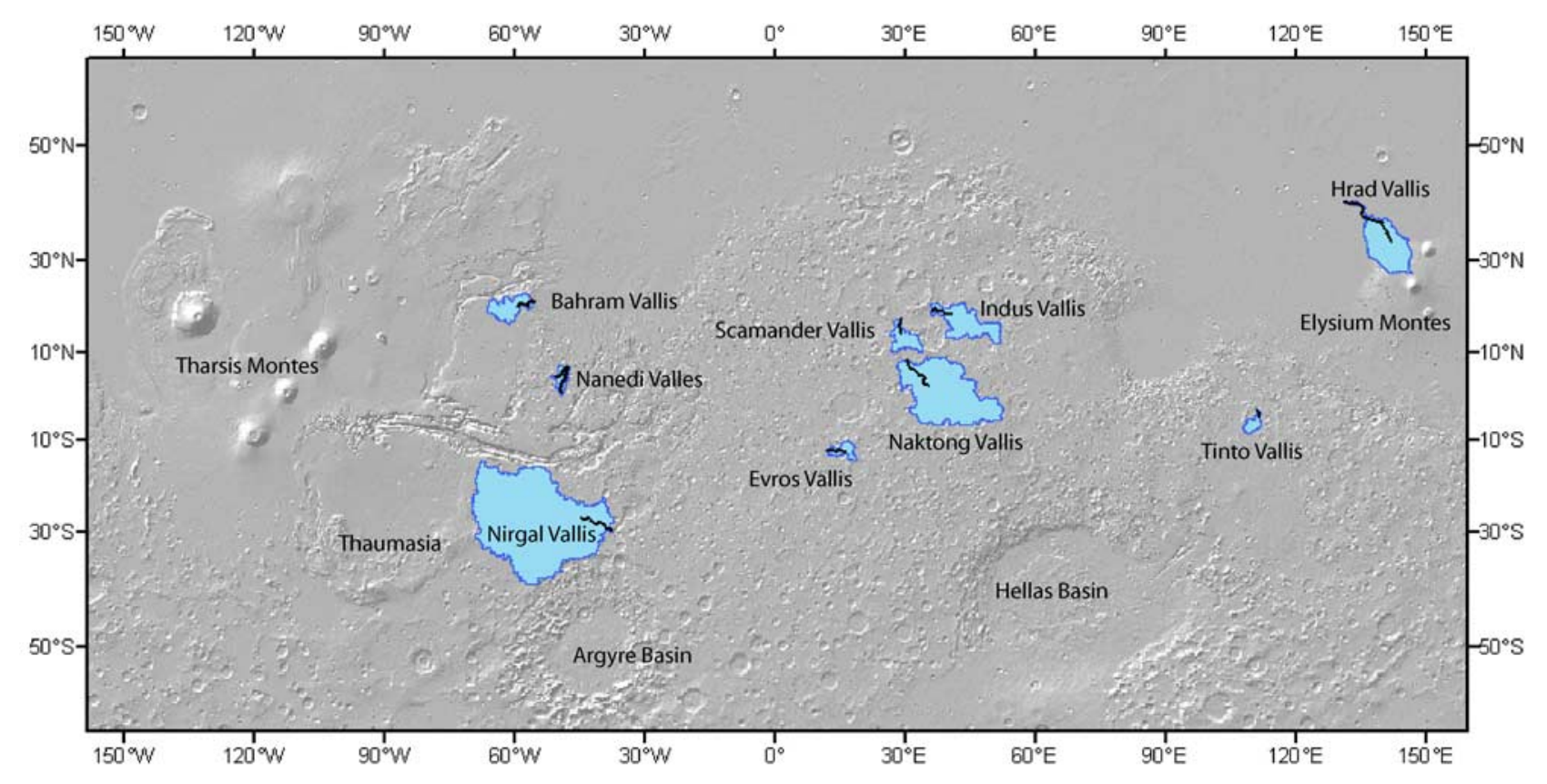

Figure 1. Geographical location of Martian valleys studied in this paper, relative to common landmarks.

to the discharge, such an assumption is necessary if we are to compare the hydraulic properties of the dendritic valleys on Mars with their precipitation formed terrestrial counterparts.

\section{Downstream Variation of Channels}

[12] We investigated for 10 Martian valleys (Figure 1 and Table 1) three relationships that are expected to hold in general for terrestrial precipitation-fed channel networks. Terrestrial perennial channels typically exhibit a predictable downstream increase in width due to downstream increase in drainage area collecting basin-wide precipitation. A graded longitudinal profile (sensu Mackin [1948]) exhibits a concave planform curvature that displays an inverse relationship between drainage area and slope. Finally, Montgomery and Dietrich [1992] compiled data from $>600$ drainage basins spanning different climatic regions around the world, and confirmed that the relationship between channel length and corresponding drainage area, or Hack's law [1957], provides a robust global empiricism for terrestrial channels.

\subsection{Width-Area Scaling}

[13] Leopold and Maddock [1953] quantified systematic downstream trends in the increase of width with drainage area for alluvial channels. The now classic terrestrial empiricism that relates how channel width $\mathrm{W}$ scales with discharge $\mathrm{Q}$ in humid terrain may be written as

$$
\mathrm{W} \propto \mathrm{Q}^{\mathrm{b}} .
$$

Numerous studies have confirmed that $\mathrm{b} \sim 0.5$ for alluvial channels [Knighton, 1998]. Montgomery and Gran [2001] reported that bedrock channels exhibited comparable trends, with $b=0.3-0.5$, in a study where drainage area A was taken as a surrogate for discharge Q, a finding strengthened by Whipple's [2004] global data compilation. As such, equation (1) can be written

$$
\mathrm{W} \propto \mathrm{A}^{\mathrm{b}} .
$$

[14] Dryland rivers [Bull and Kirkby, 2002; Thomas, 1997] found in semiarid to arid environments scale quite differently, in some ways, from humid temperate channels [Merritt and Wohl, 2003]. While Mabbutt [1977] recognized that semiarid to arid rivers decrease in width downstream, Wolman and Gerson [1978] and Reid and Frostick [1994] identified an asymptotic limit in channel width as drainage areas reached $>50 \mathrm{~km}^{2}$. In addition to the limited size of the drainage basin affected by individual rain storms, discharge sinks such as hydration of soil, evaporation and infiltration explain this apparent upper limit to the width of dryland channels. Hooke and Mant [2002] further identify a "very high variability in width" superimposed on the asymptotic trend as characteristic of dryland channels.

[15] Another important characteristic of dryland rivers is that the channel width does not necessarily record the most recent fluvial activity, but can reflect older large floods. Indeed, Wolman and Gerson [1978], for example, report that widths of dryland rivers expand to accommodate discharge surges, and following the surge, tend to remain in an expanded form. Arid channel morphology thus reflects the largest discharge surge, or possibly a compound morphology created by surges of different magnitude [Hooke and Mant, 2002], rather than the adjustment to a dominant discharge typical of perennial channels [Williams, 1978; Wolman and Miller, 1960]. Hence, the challenge inherent to the inverse problem of estimating the original discharge 
Table 1. Age and Terrain Characteristic of Valleys Studied

\begin{tabular}{|c|c|}
\hline Valley & Type and Age of Terrain Incised \\
\hline $\begin{array}{l}\text { Bahram Vallis } \\
\quad\left(302.50^{\circ} \mathrm{E}, 20.7^{\circ} \mathrm{N}\right)\end{array}$ & $\begin{array}{c}\text { Hesperian ridged plains material }^{\mathrm{a}} \\
\text { Early Hesperian }^{\mathrm{b}}\end{array}$ \\
\hline $\begin{array}{l}\text { Evros Vallis } \\
\quad\left(13.5^{\circ} \mathrm{E}, 12.5^{\circ} \mathrm{N}\right)\end{array}$ & Noachian hilly and cratered material ${ }^{\mathrm{a}}$ \\
\hline $\begin{array}{l}\text { Hrad Vallis } \\
\quad\left(135.3^{\circ} \mathrm{E}, 38.4^{\circ} \mathrm{N}\right)\end{array}$ & Hesperian rolling plains material ${ }^{\mathrm{a}}$ \\
\hline $\begin{array}{l}\text { Indus Vallis } \\
\left(39^{\circ} \mathrm{E}, 19^{\circ} \mathrm{N}\right)\end{array}$ & Noachian hilly and cratered material ${ }^{\mathrm{a}}$ \\
\hline $\begin{array}{l}\text { Naktong Vallis } \\
\quad\left(35.4^{\circ} \mathrm{E}, 1.7^{\circ} \mathrm{N}\right)\end{array}$ & Noachian hilly and cratered material ${ }^{\mathrm{a}}$ \\
\hline $\begin{array}{l}\text { Nanedi Valles } \\
\quad(\text { main }+ \text { trib.) } \\
\left(311.7^{\circ} \mathrm{E}, 5^{\circ} \mathrm{N}\right)\end{array}$ & $\begin{array}{c}\text { Noachian cratered plateau terrain } \\
\text { Late Noachian }\end{array}$ \\
\hline $\begin{array}{l}\text { Nirgal Vallis } \\
\quad\left(319^{\circ} \mathrm{E}, 28^{\circ} \mathrm{N}\right)\end{array}$ & $\begin{array}{c}\text { Noachian cratered plateau terrain }{ }^{\mathrm{a}} \\
\text { Early Hesperian }^{\mathrm{b}}\end{array}$ \\
\hline $\begin{array}{l}\text { Scamander Vallis } \\
\left(29.90^{\circ} \mathrm{E}, 14.25^{\circ} \mathrm{N}\right)\end{array}$ & $\begin{array}{l}\text { Noachian cratered plateau terrain }{ }^{\mathrm{a}} \\
\text { Middle Noachian }\end{array}$ \\
\hline $\begin{array}{l}\text { Tinto Vallis } \\
\qquad\left(111.5^{\circ} \mathrm{E}, 4.5^{\circ} \mathrm{N}\right)\end{array}$ & Amazonian cratered plains material ${ }^{\mathrm{a}}$ \\
\hline
\end{tabular}

${ }^{\mathrm{a}}$ Skinner at al. [2006].

${ }^{\mathrm{b}}$ Harrison and Grimm [2005].

based solely on morphology becomes particularly relevant for Mars.

[16] Nonetheless, this scaling relationship (equation (2)) provides robust expectations for trends in drainage area and valley width scaling if indeed Martian valleys were carved by precipitation distributed across a drainage basin. This assumption underpinning downstream variation in channel scaling does not hold if the source is discrete, as illustrated by relations for terrestrial point source discharges such as dam-break floods, or if precipitation was only active over a portion of the drainage basin at a time, as in terrestrial dryland rivers.

[17] In contrast to the typical interpretation of Martian valley networks, large, catastrophic point source release of water is commonly cited as the main cause of the Martian outflow channels [Carr, 1996]. The multiple, catastrophic drainage events of Pleistocene lakes such as lake Missoula are the closest Earth analogs in terms of scale [Komar, 1980]. Measuring downstream variations in channel widths of large outbursts such as Lake Missoula can prove challenging, where the flows were anastamosing over a large scale. However, spillways cut by lake outbursts when glacial retreat released large quantities of stored meltwater are characterized by lack of major tributaries (except, of course, for other spillways), as well as deeply entrenched constant-width channels, and commonly terminate at large coarse-grained sediment fans [Kehew and Lord, 1987]. Hence, a relatively constant downstream width provides a key distinguishing characteristic of channels carved by point sourced outburst floods.

[18] The difference in acceleration due to gravity on Mars does affect the absolute width of the channels, but not their overall trend (and hence won't change the value of the exponent $b$ ). By expanding the scaling relationship obtained by Finnegan et al. [2005] to include the acceleration due to the gravity term g, we find (Appendix A)

$$
W \propto Q^{3 / 8} g^{-3 / 16} S^{-3 / 16},
$$

where $\mathrm{W}$ is channel width, $\mathrm{Q}$ is discharge, and $\mathrm{S}$ is slope; from which (assuming the same discharge and slope) one can derive

$$
W_{\text {Earth }}=0.8 \cdot W_{\text {Mars }} \text { or } W_{\text {Mars }}=1.25 \cdot W_{\text {Earth }},
$$

as reported by Irwin et al. [2005a].

\subsection{Slope-Area Scaling}

[19] The propensity for the equilibrium form of river profiles to be concave (to decrease in slope downstream) has long been recognized on the basis of an erosional tradeoff between slope and discharge [Gilbert, 1877]. Whipple and Tucker [1999] derived predicted scaling relations of river slope with drainage area by postulating that erosion rate is a power function of shear stress [Howard, 1994; Howard and Kerby, 1983]. Assuming a balance between rock uplift and river incision, they show that slope $\mathrm{S}$ can be related to drainage area $\mathrm{A}$ as

$$
\mathrm{S} \propto \mathrm{A}^{-\theta}
$$

where $\theta$ is the river profile concavity. In this context, the value of 0.5 derived for $\theta$ from theoretical grounds is close to values of $0.4-0.5$ typical of active terrestrial orogens [Whipple and Tucker, 1999]. However, $\theta$ also has been observed to vary between 0.22 and 0.63 for nonequilibrium channels incising a rift margin in the Sierra Madre Occidental, Mexico [Montgomery and Lopez-Blanco, 2003]. As such, the value of the concavity cannot constrain whether the channel is in equilibrium. In contrast, dryland rivers do not display similar values of concavity. Instead, measurements of their longitudinal profiles suggest a lack of downstream variability in slope [e.g., Hooke and Mant, 2002; Navarro Hervas, 1991]. Nonetheless, positive values of $\theta$, translating into concave-up longitudinal profiles (positive curvature), are expected for nonarid channels carved by precipitation-fed flows.

\subsection{Langbein's Concavity Index}

[20] Langbein [1964] proposed a drainage area independent index of concavity (that we term the Langbein concavity index (LCI) to avoid confusion with $\theta$ defined above). On the basis of the shape of the channel longitudinal profile, it is defined as

$$
\mathrm{LCI}=2 \mathrm{~h} / \mathrm{H},
$$

where $\mathrm{H}$ is total fall and $\mathrm{h}$ is the height difference between the profile at middistance and a straight line joining the end points of the profile [Knighton, 1998]. This simple method for finding the sign of the concavity (positive values equating to concave profiles and negative values to convex profiles) has the advantage of not assuming that a surfacedefined area produces the channel forming runoff. For reference, the Rhine and the Amazon rivers have LCI values of 1.14 and 1.07, respectively [Knighton, 1998].

\subsection{Hack's Law}

[21] The scaling relationship between channel length and drainage area [Hack, 1957] is a robust empiricism for perennial and ephemeral channels through the full range 
of drainage area size on Earth [Montgomery and Dietrich, 1992]. It is commonly written as

$$
\mathrm{L} \propto \mathrm{A}^{\mathrm{n}}
$$

where $\mathrm{L}$ is the channel length and $\mathrm{A}$ the drainage area. Whereas Hack [1957] found a value of 0.6 for $n$, he suggested that $\mathrm{n}$ might vary somewhat depending on the area of study. Mueller [1973] reports a changing $\mathrm{n}$ value from 0.6 to $\sim 0.5$ with increasing network size. Montgomery and Dietrich [1992] report a value of 0.49 for their composite data set, in which they assembled more than 600 perennial and ephemeral channels ranging in size from $1000 \mathrm{~m}^{2}$ to the Amazon river $\left(\sim 7 \times 10^{6} \mathrm{~km}^{2}\right)$. Consequently, values of $\sim 0.5-0.6$ are expected for fluvial systems in general.

\section{Methodology}

[22] Defining a drainage basin on a surface being actively cratered is difficult because of the intricacies of basin disruptions and fragmentations from the impact cratering [Howard, 2007]. However, most of the valleys chosen in this study postdate the period of intense cratering $(>3.7 \mathrm{Ga})$ [Hartmann, 2005] except, perhaps, for Evros Vallis, on the basis of their crisp valley boundaries and poorly cratered valley floor (compared with the surrounding plains), as described in section 4. As such, the DEM-computed drainage areas may reasonably represent topographically defined basins typical of conditions that existed during incision. Furthermore, because of an impact-gardened, thick $(\sim 2 \mathrm{~km})$, porous (10-20\%) megaregolith [Carr, 1986], runoff that may have accumulated in craters could have connected with groundwater originating from deposition and infiltration on the intercrater plains.

[23] For each valley large enough to be analyzed with MOLA (using the 128 pixel per degree MOLA DEM having a resolution of $\sim 460 \mathrm{~m}$ per pixel [Smith et al., 2003]), we selected an area on the DEM larger than the topographically defined drainage basin. This new map was imported into ARC/INFO [Environmental Systems Research Institute, 1997] and pits were filled to avoid discontinuities in defining flow direction and the calculation of the drainage areas. Following the fill, grids of flow direction and flow accumulation were computed by finding the direction of steepest slope from each grid cell, and keeping track of how many cells flow into each downstream cell. Valleys were identified as cells of concentrated flow that coincided in map view with features apparent in higherresolution THEMIS images [Christensen et al., 2004]. Following this, thirty evenly spaced $50 \mathrm{~km}$ cross sections were generated down the main valley for the purpose of measuring valley width, with the corresponding drainage area computed at each location. The map view of the cross sections was overlapped with Mars Global Surveyor ground tracks, and whenever the cross section fell into a zone of poor MOLA coverage, in which interpolation artifacts discernibly influenced representation of valley form [Som et al., 2008], those cross sections were excluded from further analysis.

[24] Width measurements were taken from registered THEMIS VIS images at the same location as the MOLA cross sections, as identified by definable topographical breaks visible on the higher-resolution THEMIS images. Because of the coarseness of the MOLA data compared with the THEMIS VIS images, our automatic cross-section selection routine did not necessarily capture the cross section perpendicular to the valley. As needed, this was corrected using the THEMIS VIS images processed using the Integrated Software for Images and Spectrometers (ISIS; http://isis.astrogeology.usgs.gov). All conclusions in this paper regarding width measurements are inferred from THEMIS VIS measurements, although both THEMIS VIS and MOLA results are reported.

[25] Valley slope was obtained by following a method similar to Howard et al. [2005], in which adjacent $3 \mathrm{~km}$ diameter circles were aligned along a valley centerline. Within each circle, all raw MOLA elevation measurements were analyzed to find the one with the lowest elevation, generally indicating valley floor. At this location, the corresponding drainage area was computed. The loci of such points formed the longitudinal profile. A topographic profile paralleling the valley profile but laterally offset $3 \mathrm{~km}$ away was obtained from the DEM to give each profile regional context.

\section{Study Areas and Results}

[26] The valleys in this study incise a variety of terrain, and span the planet geographically (Figure 1). In discussing the terrain age, we use the geologic timescale for Mars, as refined by Hartmann and Neukum [2001]. This timescale is divided into 3 periods: Noachian, Hesperian, and Amazonian. On the basis of impact crater density, with age extrapolated from the lunar record, the Noachian-Hesperian boundary is estimated to be at $\sim 3.5-3.7 \mathrm{Ga}$, while the Hesperian-Amazonian boundary is set at $2.9-3.3 \mathrm{Ga}$ [Hartmann and Neukum, 2001]. The valleys studied span all three time periods (Table 1).

\subsection{Bahram Vallis}

[27] Bahram Vallis $\left(302.50^{\circ} \mathrm{E}, 20.7^{\circ} \mathrm{N}\right)$ is $350 \mathrm{~km}$ long, trending east-west, and flowing from Lunae Planum to Chryse Planitia (Figure 2). Its drainage area is $121,300 \mathrm{~km}^{2}$, but because of the wrinkle ridges in Lunae Planum that likely postdate the valley, this value is taken as a minimum. On the basis of crater counts, Lunae Planum is Hesperian in age, making the age of Bahram Vallis at most early Hesperian [Harrison and Grimm, 2005]. Although no channel is apparent within the valley, evidence of surface flow is present in the first third of the valley. THEMIS image V12509005 (Figure 2b) shows evidence of streamlined islands. Image V02536006 (Figure 2c) shows an apparently older (more heavily cratered) terrace next to the relatively craterless valley floor suggesting multiple events of surface flow. The source region is ambiguous and seems to have been altered by (1) ejecta from the Pompeii crater and (2) a wrinkle ridge, characteristic of Lunae Planum. The valley walls are lined with alcoves, appearing dominantly on the south facing slopes.

[28] Bahram Vallis is the only studied valley with a concave longitudinal profile incised in convex topography (Figure 3), resulting in substantial incision of the valley below the regional terrain surface. However, its drainage area hardly increases downstream. Bahram Vallis has scal- 


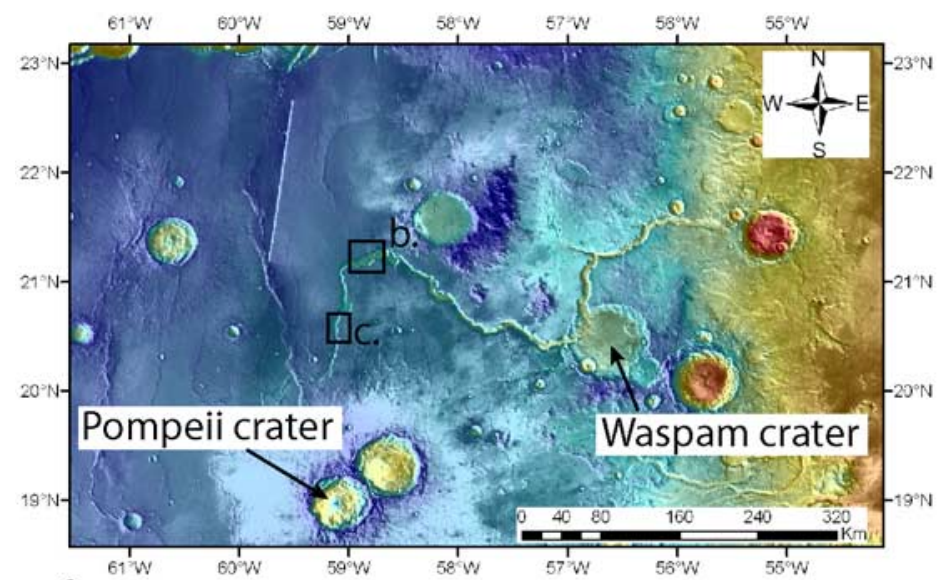

a.

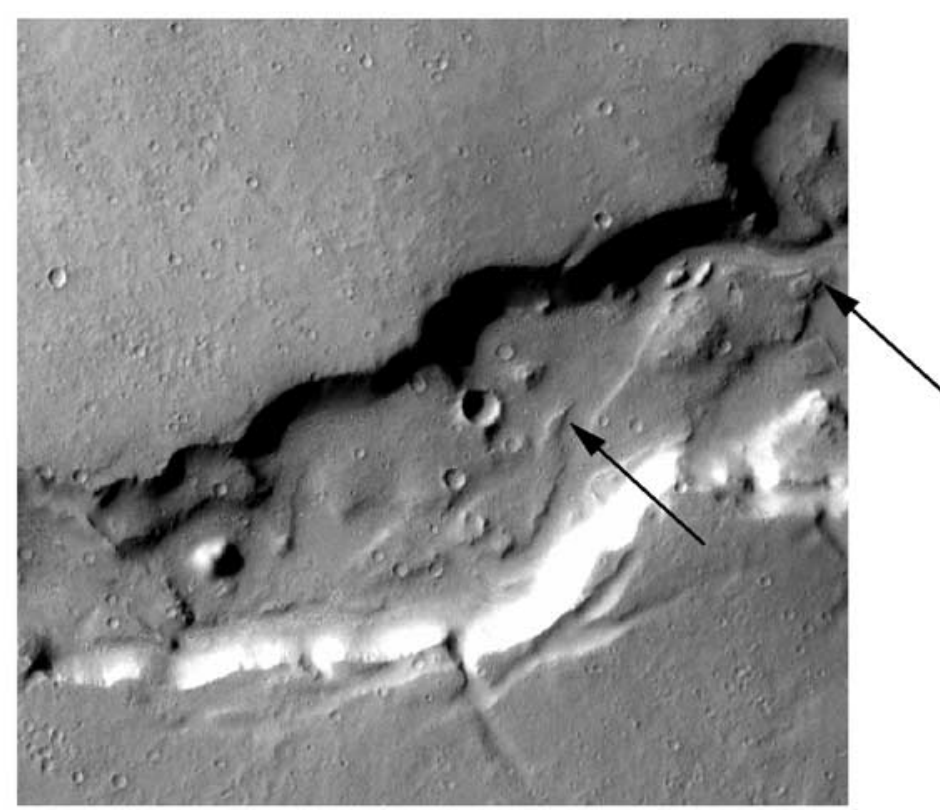

b.

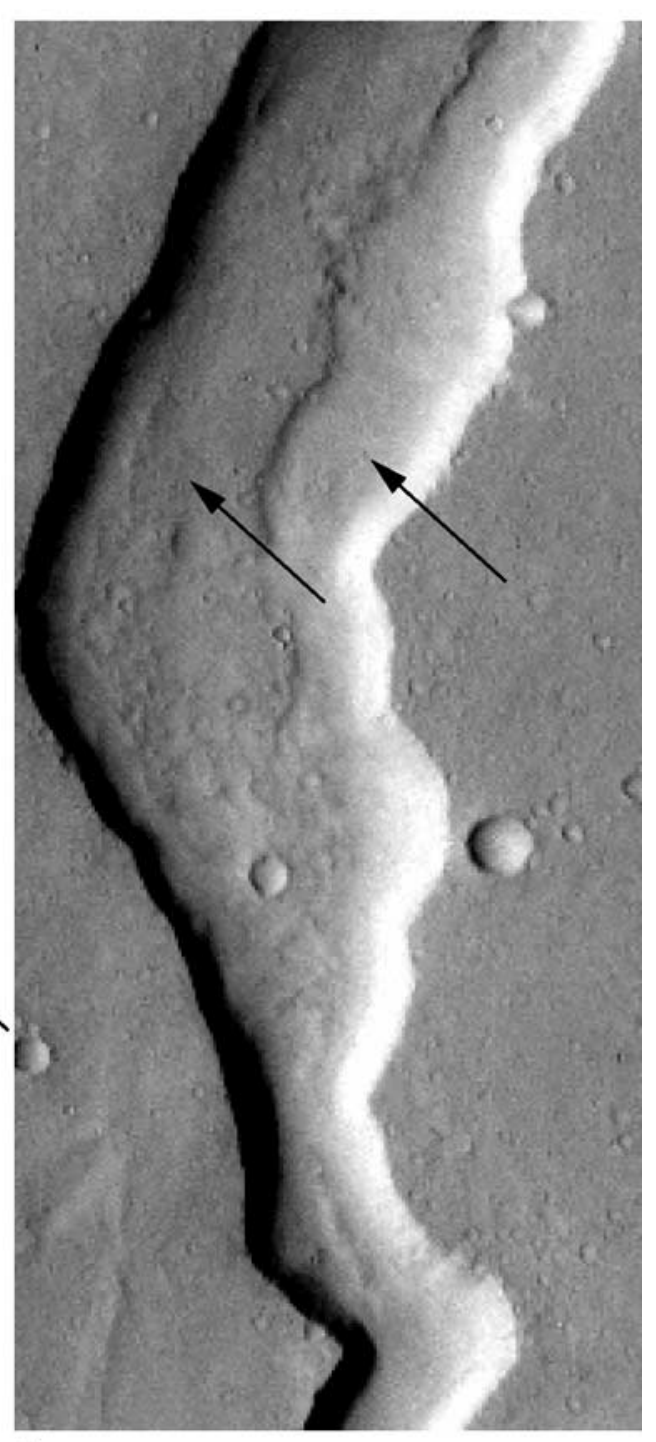

C.

Figure 2. (a) Context map of Bahram Vallis. (b) V12509005 detail: Evidence of surface flow (arrows). (c) V02536006 detail: Different age surfaces (based on crater density) within Bahram Vallis (arrows).

ing exponents $\mathrm{b}, \theta$, and $\mathrm{n}$ equal to $2.45,5.46$, and 9.79 , respectively (Figure 3).

\subsection{Nirgal Vallis}

[29] Nirgal Vallis $\left(319^{\circ} \mathrm{E}-28^{\circ} \mathrm{N}\right)$ is a $550 \mathrm{~km}$ east-west trending valley that incises early Hesperian terrain [Harrison and Grimm, 2005] (Figure 4). It flows east into Uzboi Vallis, an outflow channel that drains north into Holden crater, where evidence of perennial surficial water has been inferred in the form of a fossil meander and alluvial fans [Bhattacharya et al., 2005; Malin and Edgett, 2003]. Nirgal Vallis is characterized by short dendritic tributaries to the west [Baker et al., 1992; Sharp and Malin, 1975], with amphitheater head terminations, located dominantly in the first half of the valley. Morphologic evidence of surface flow is seen in THEMIS image V01837003 [Irwin et al., 2005a] (Figure 4b).

[30] Nirgal Vallis has a convex longitudinal profile (Figure 5) similar to that of the terrain it incises (although curious long-wavelength irregularities in slope are observed in the last $150 \mathrm{~km}$ ), and has an extensive drainage basin of $1.5 \times 10^{6} \mathrm{~km}^{2}$, almost twice as large as the next largest of the studied basins (Naktong Vallis with $8.5 \times 10^{5} \mathrm{~km}^{2}$ ). Nirgal Vallis has scaling exponents $b, \theta$, and $n$ equal to 2.59, -2.50 , and 4.94, respectively (Figure 5).

\subsection{Scamander Vallis}

[31] Scamander Vallis [Baker and Partridge, 1986; Carr and Malin, 2000] appears to begin in a $\sim 25 \mathrm{~km}$ diameter crater located at $29.90^{\circ} \mathrm{E}, 14.25^{\circ} \mathrm{N}$, and incises to the north into mid-Noachian terrain [Harrison and Grimm, 2005] (Figure 6). The absence of significant cratering on the valley floor and crisp valley boundaries, however, implies a relatively young valley. It has been inferred that Scamander Vallis is a segment of a much longer $4700 \mathrm{~km}$ valley [Irwin et al., 2005b], which would suggest that the crater from which Scamander originates is younger than the valley itself. However, in THEMIS image V01734006 (Figure 6b), 

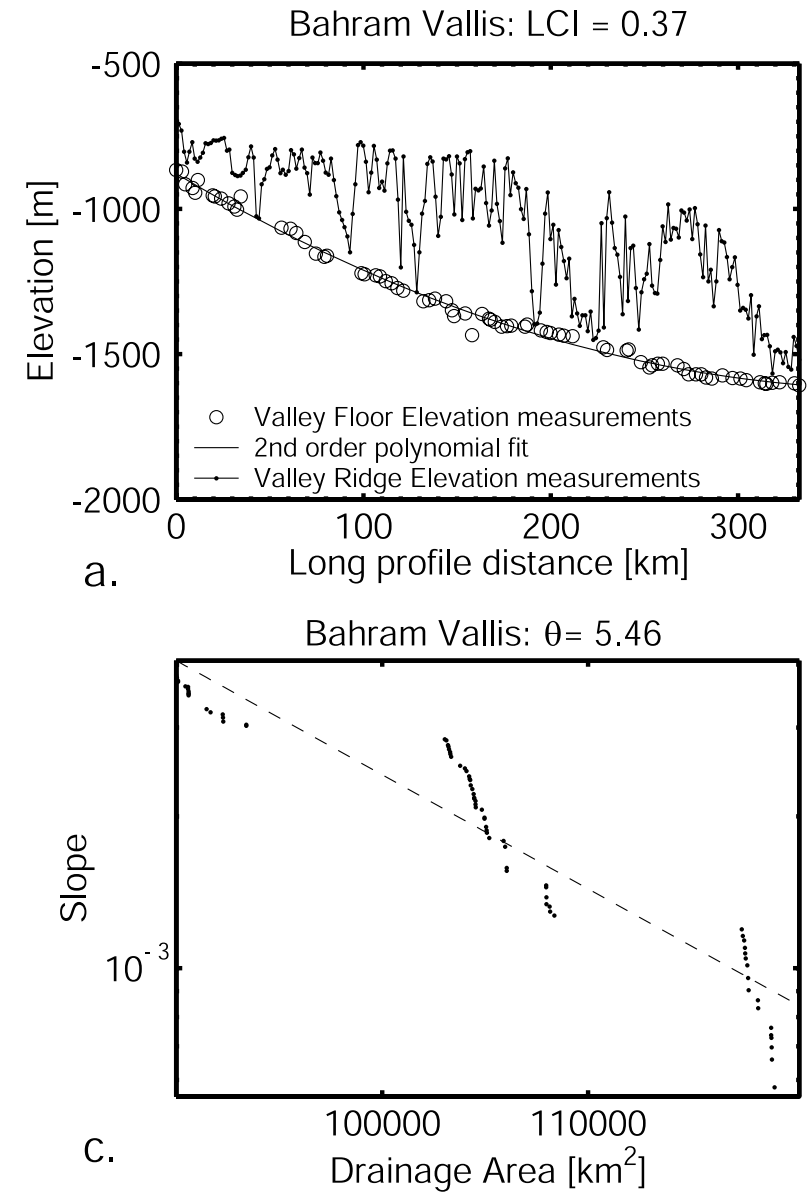
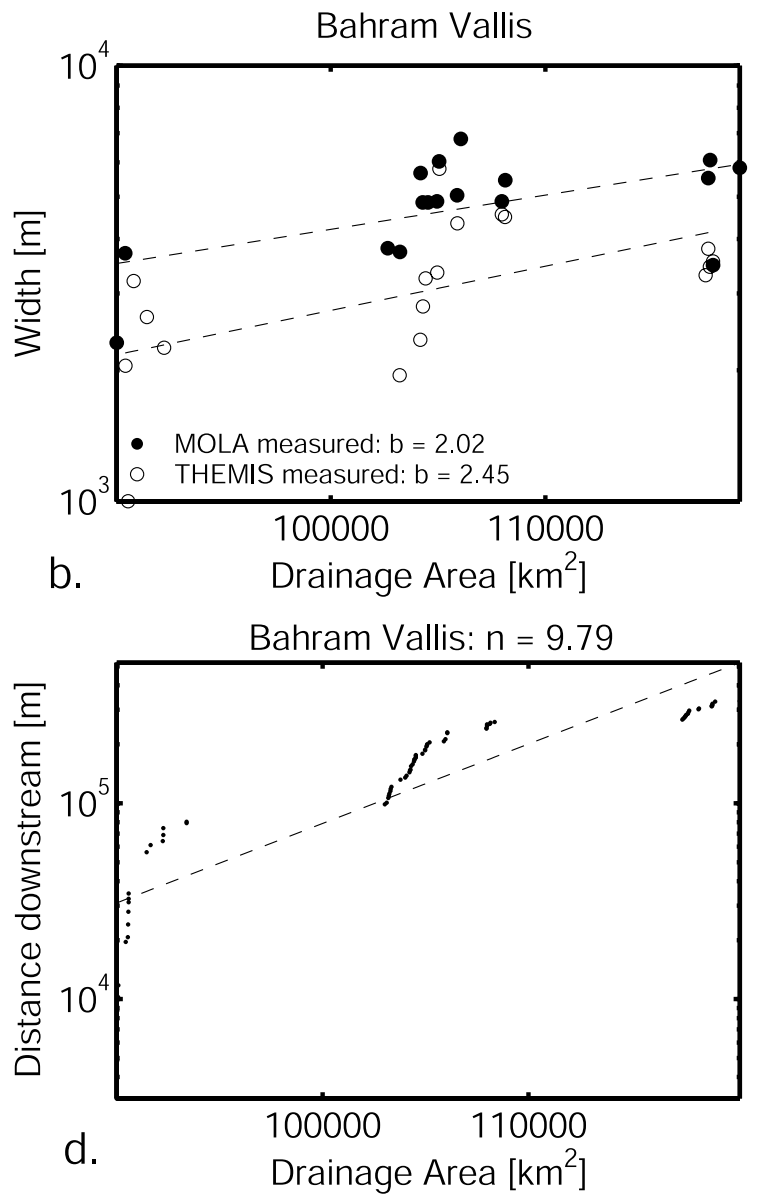

Figure 3. Topographic and scaling results for Bahram Vallis. (a) Longitudinal profile (circles) along with valley ridge topography (3 $\mathrm{km}$ away from valley centerline). (b) Valley width versus drainage area measurements obtained with MOLA (dots) and THEMIS (circles). (c) Valley slope versus drainage area. (d) Valley length downstream versus drainage area.
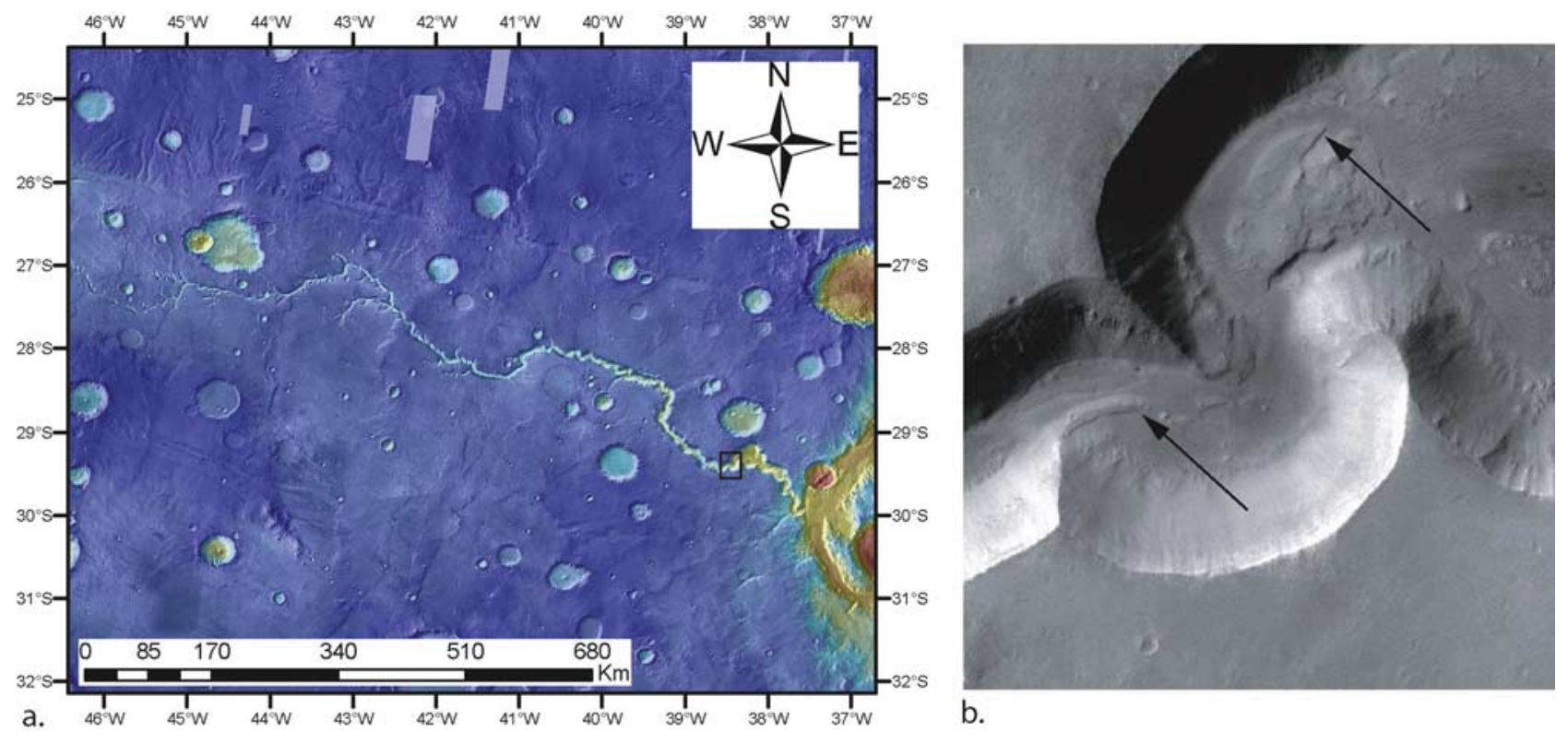

b.

Figure 4. (a) Context map of Nirgal Vallis. (b) V01837003 detail: Surface flow evidence within Nirgal Vallis (arrows). 

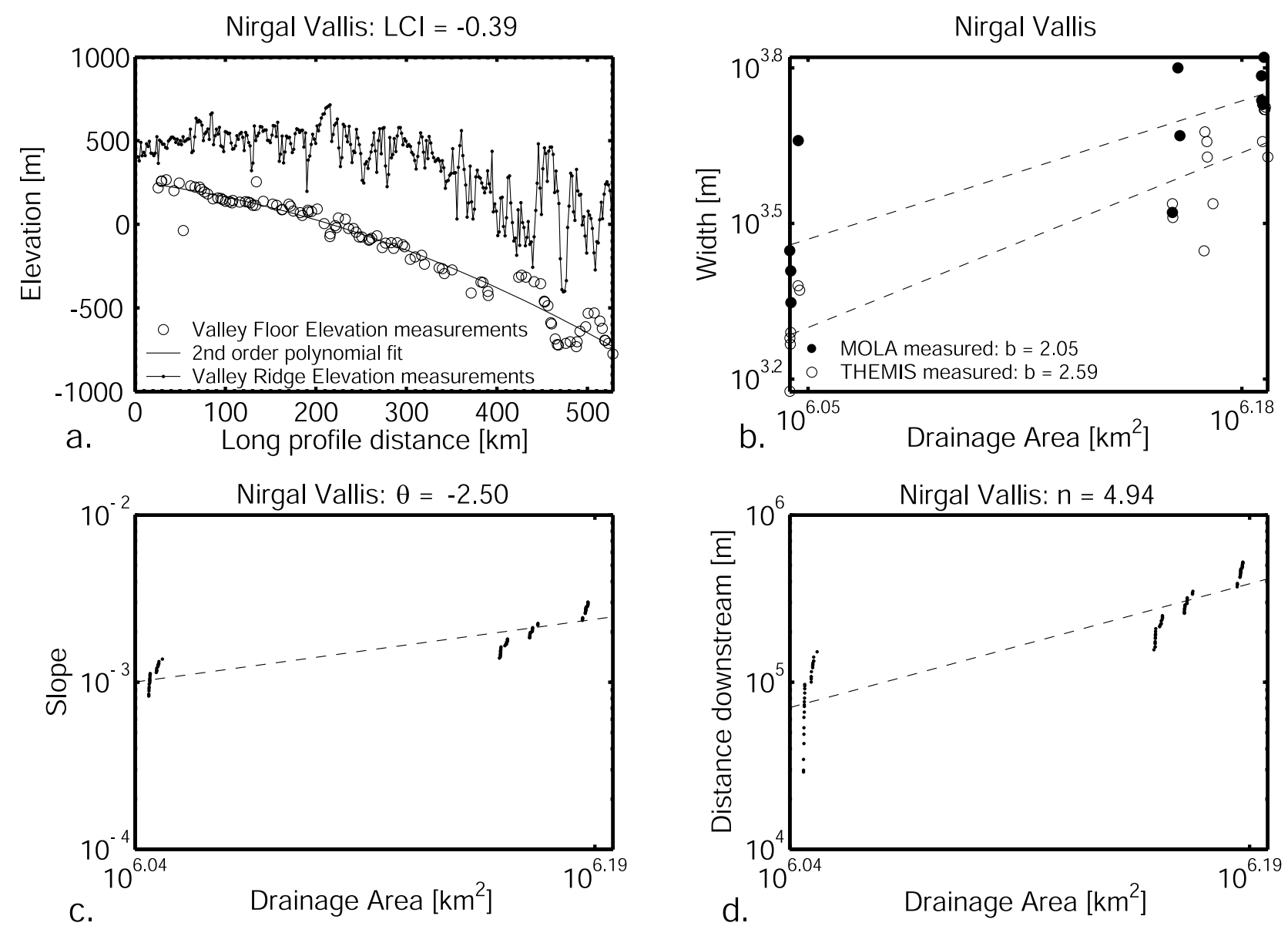

Figure 5. Topographic and scaling results for Nirgal Vallis (a-d are as in Figure 3).

Scamander Vallis breaches the crater rim, indicating the crater is older than the valley. Although one could argue that the crater formed a lake in between valley reaches, we find no evidence of sediment deposition or other layering, as is observed, for example, in Holden crater [Grant et al., 2008]. Consequently, we treat Scamander Vallis as a discrete valley.

[32] Scamander Vallis is characterized by a quasi-linear longitudinal profile that parallels the regional topography (Figure 7), and narrows slightly downstream $(|\mathrm{b}|<1$ ). Scamander Vallis has scaling exponents $b, \theta$, and $n$ of $-0.67,-0.92$, and 7.26, respectively (Figure 7).

\subsection{Evros Vallis}

[33] Located in the Southern Highlands, Evros Vallis $\left(13.5^{\circ} \mathrm{E}-12.5^{\circ} \mathrm{N}\right)$ is a $350 \mathrm{~km}$ long valley that has the highest mean elevation $(650 \mathrm{~m})$ of the 10 large valleys examined in this study (Figure 8), and is likely the oldest [Fassett and Head, 2008]. The steepening of the valley profile $\sim 200 \mathrm{~km}$ downstream is also reflected in the regional topography, and is thus unlikely to represent an artifact of fluvial incision. Other knickpoints are identified at the joining of tributary-like features and the main valley [Howard et al., 2005]. The sharp bend observed in THEMIS image V01648003 (Figure 8b) likely represents a structural control [Schumm, 1974] on the morphology. As Evros Vallis lacks any surface evidence of active water flow (such as streamlined islands), its valley bottom is likely covered with secondary infilling, such as dune fields.

[34] Evros Vallis' longitudinal profile has a slight convexity that mirrors regional topography (Figure 9), with little downstream trend in width. It has scaling exponents $b$, $\theta$, and $\mathrm{n}$ of $0.01,-0.61$, and 2.41 , respectively (Figure 9).

\subsection{Hrad Vallis}

[35] Located in the northern plains, Hrad Vallis $\left(135.3^{\circ} \mathrm{E}\right.$, $38.4^{\circ} \mathrm{N}$ ) originates from a $\sim 370 \mathrm{~m}$ deep graben on the flanks of the Elysium Montes volcanic province [Wilson and Mouginis-Mark, 2003], and flows northwest for $\sim 885 \mathrm{~km}$ into Utopia Planitia (Figure 10). It is the longest valley in this study and the most sinuous (sinuosity = 1.57). Compelling evidence of surface flow is apparent as a teardropshaped island in THEMIS image V10780005 (Figure 10b). Wilson et al. [2004] find that water initially $\sim 300 \mathrm{~m}$ deep (a depth similar to the graben depth in which Hrad Vallis originates) may travel $2100 \mathrm{~km}$ under current Martian conditions, much farther than the length of Hrad Vallis. The longitudinal profile of Hrad Vallis parallels that of the regional surface topography (Figure 11), with little downstream change in width. Hrad Vallis has scaling exponents $\mathrm{b}, \theta$, and $\mathrm{n}$ of $0.01,-0.21$, and 0.53 , respectively (Figure 11). 


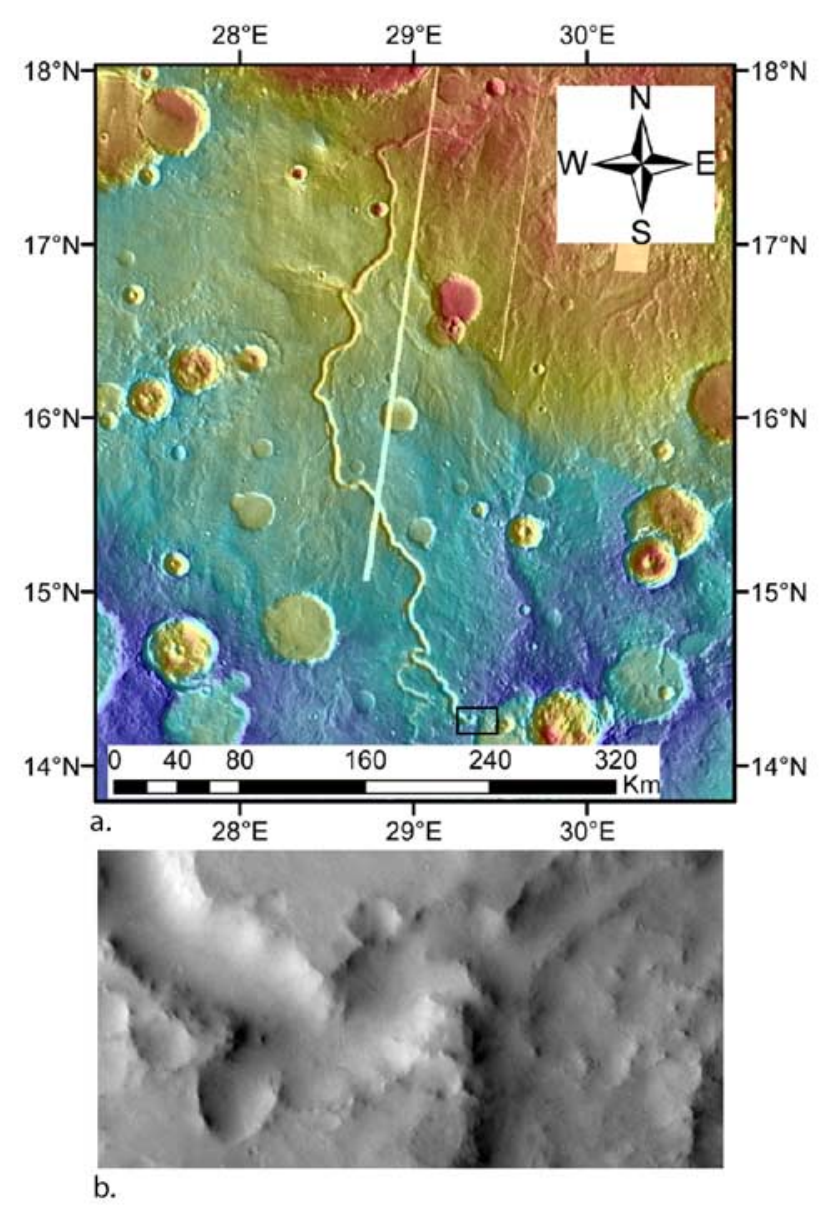

Figure 6. (a) Context map of Scamander Vallis. (b) V01734006 detail: Source of Scamander Vallis.

\subsection{Nanedi Valles}

[36] Nanedi Valles is the only Martian valley we analyzed that has a substantial tributary (Figure 12a). As such, we analyzed both its tributary (the western branch) and the main valley (the eastern branch) as independent valleys. Smaller tributaries are poorly developed and like Nirgal Vallis, begin in amphitheater shaped valleys [Harrison and Grimm, 2005]. Located at $311.7^{\circ} \mathrm{E}, 5^{\circ} \mathrm{N}$, Nanedi Vallis flanks the Shalbatana Vallis outflow channel. Nanedi Valles incises late Noachian terrain, but its crisp edges suggest younger incision. On the basis of crater counts, an early Hesperian age is usually assigned for Nanedi Valles [Harrison and Grimm, 2005]. The main valley of Nanedi Valles is highly unusual in that it has extremely tight meanders for $\sim 50 \mathrm{~km}$ of its $520 \mathrm{~km}$ length. Tight meanders are usually an expression of perennial flow, but the longitudinal profile is inconsistent with a graded topographic form, so the nature of the tight meanders remains puzzling. Yet, such morphology is hard to explain without invoking surficial flow, as posited by Malin and Carr [1999] and Carr and Malin [2000] on the basis of MOC images E0501620 and AB1-8704 that show an apparent channel incised on the valley floor (Figure 12b). We choose to end
Nanedi Valles shortly after the merging of the main tributary, since its genetic relationship with Hypanis Vallis to the north is unclear (although Carr and Malin [2000] extend Nanedi Valles another $\sim 350 \mathrm{~km}$ to the north). The main valley of Nanedi Valles (prior to merger) has scaling exponents $\mathrm{b}, \theta$, and $\mathrm{n}$ of $0.34,-5.8$, and 22.4 , respectively (Figure 13).

[37] The main tributary of Nanedi Valles originates from a highly cratered province directly northeast of Mutch Crater $\left(304.7^{\circ} \mathrm{E}, 0.5^{\circ} \mathrm{N}\right)$. Unlike the main valley, it does have a few tributaries, one of which is particularly developed with thirdorder branching apparent on THEMIS image I10724003 (Figure 12c). However, even those branches begin at amphitheater head terminations.

[38] Like the main valley it joins, the profile of the main tributary of Nanedi Valles parallels that of the surrounding terrain, with a linear profile and no distinct downstream trend in width. Nanedi Valles' main tributary has scaling exponents $\mathrm{b}, \theta$, and $\mathrm{n}$ of $<0.01,-0.01$, and 0.98 , respectively (Figure 14).

\subsection{Naktong Vallis}

[39] Naktong Vallis appears to begin $\sim 5 \mathrm{~km}$ north from a small $\sim 20 \mathrm{~km}$ in diameter unnamed crated located at $35.4^{\circ} \mathrm{E}, 1.7^{\circ} \mathrm{N}$ (Figure 15). The valley flows north for $740 \mathrm{~km}$ until debouching directly south of Arago crater. It is part of a $4700 \mathrm{~km}$ valley system that Irwin et al. [2005b] propose. Yet, while Naktong Vallis incises the north ejecta blanket of the unnamed source crater (THEMIS image V11370014, Figure 15b), no such incision is seen on the southern part of the ejecta blanket (THEMIS image V17198011 and I17198010, Figure 15c). As such, like Scamander Vallis, we choose to treat Naktong Vallis as a discrete valley. Naktong Vallis has scaling exponents $\mathrm{b}, \theta$, and $\mathrm{n}$ of $0.04,0.07$, and 0.47 , respectively (Figure 16).

\subsection{Indus Vallis}

[40] Indus Vallis $\left(39^{\circ} \mathrm{E}, 19^{\circ} \mathrm{N}\right)$ is located directly east of the Cassini impact basin (Figure 17). It flows west into an unnamed $\sim 25 \mathrm{~km}$ diameter crater, and flows out of it heading south. The valley ends flowing west into an unnamed $\sim 70 \mathrm{~km}$ diameter crater. Some material eroded from the valley appears to have been deposited within that crater. Moreover, since its path intersects several craters, it is likely younger than the terrain it incises. Indus Vallis has the unusual characteristic (for Mars) of having an inset channel clearly incised into the floor of an apparent valley (e.g., THEMIS image I17797018, Figure 17b), and is, to our knowledge, the only valley visible at the MOLA resolution that contains such an incised channel, although the relationship between the incised channel and the valley is unclear. As such, we used the widths of the incised channel, and not valley widths for Indus Vallis. Indus Vallis has scaling exponents $\mathrm{b}, \theta$, and $\mathrm{n}$ of $2.2,0.11$, and 0.48 , respectively (Figure 18).

\subsection{Tinto Vallis}

[41] Tinto Vallis $\left(111.5^{\circ} \mathrm{E}-4.5^{\circ} \mathrm{N}\right)$ [Carr, 1995; Carr and Malin, 2000] is a short $(\sim 160 \mathrm{~km})$ valley that flows northward into the $\sim 50 \mathrm{~km}$ wide Palos crater, located $\sim 1000 \mathrm{~km}$ southeast of the Isidis impact basin (Figure 19). It incises the surrounding terrain deeply $(>600 \mathrm{~m})$. Its 

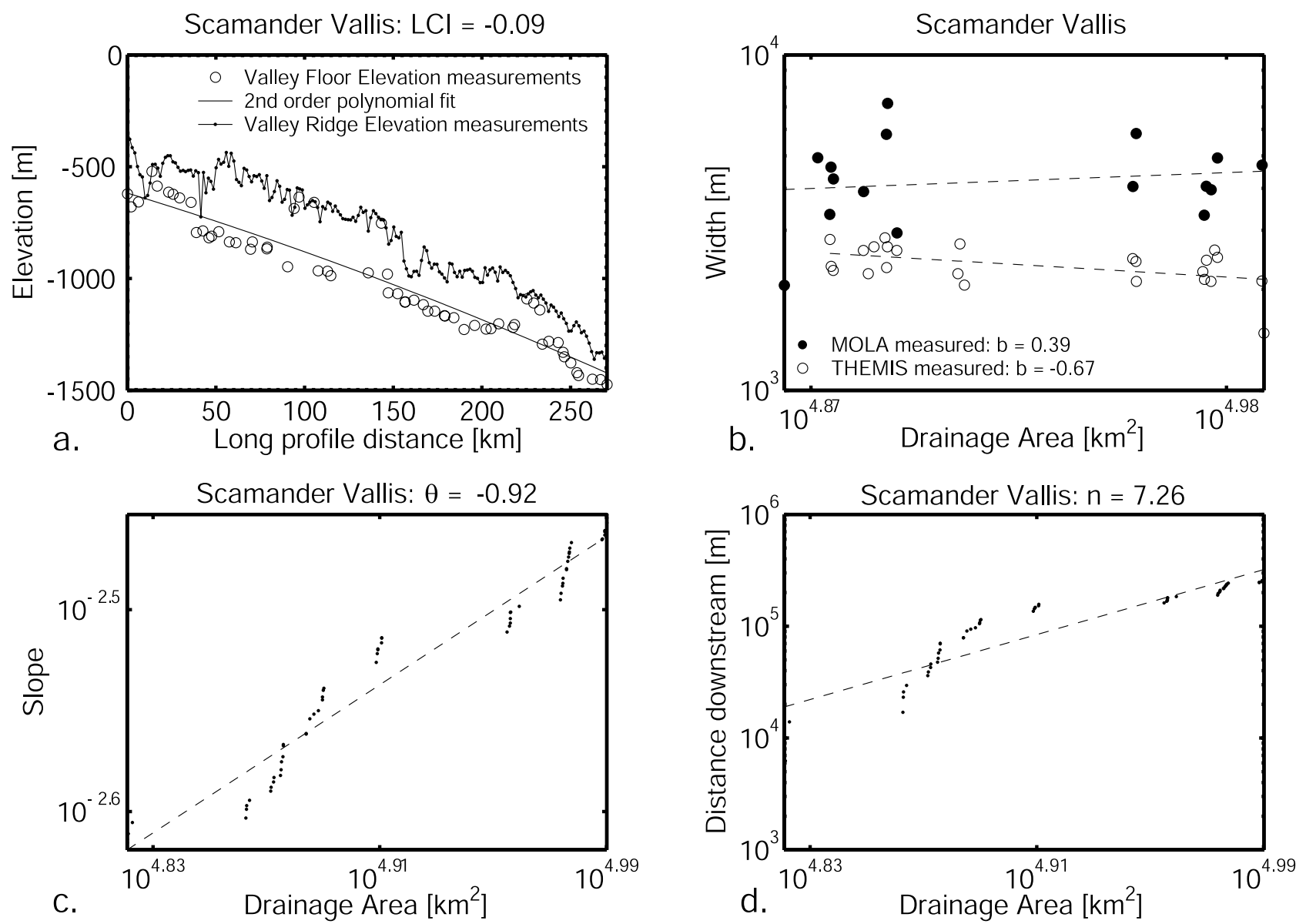

Figure 7. Topographic and scaling results for Scamander Vallis ( $-\mathrm{d}$ are as in Figure 3). The first four segments in the distance downstream versus drainage area plot have a combined $\mathrm{n}$ value of 19.4, compared with $\mathrm{n}=2.9$ for the last three.

surface morphology is very similar to Scamander Vallis; it has crisp valley boundaries with few impact craters within its walls (e.g., THEMIS image V17708002, Figure 19b). The depressions that characterize the source of Tinto Vallis

have been interpreted as consistent with a subsurface origin for the fluids that caused incision [Carr and Malin, 2000]. Tinto Vallis has scaling exponents $b, \theta$, and $\mathrm{n}$ of $4.7,-25.6$, and 19.2 , respectively (Figure 20 ).
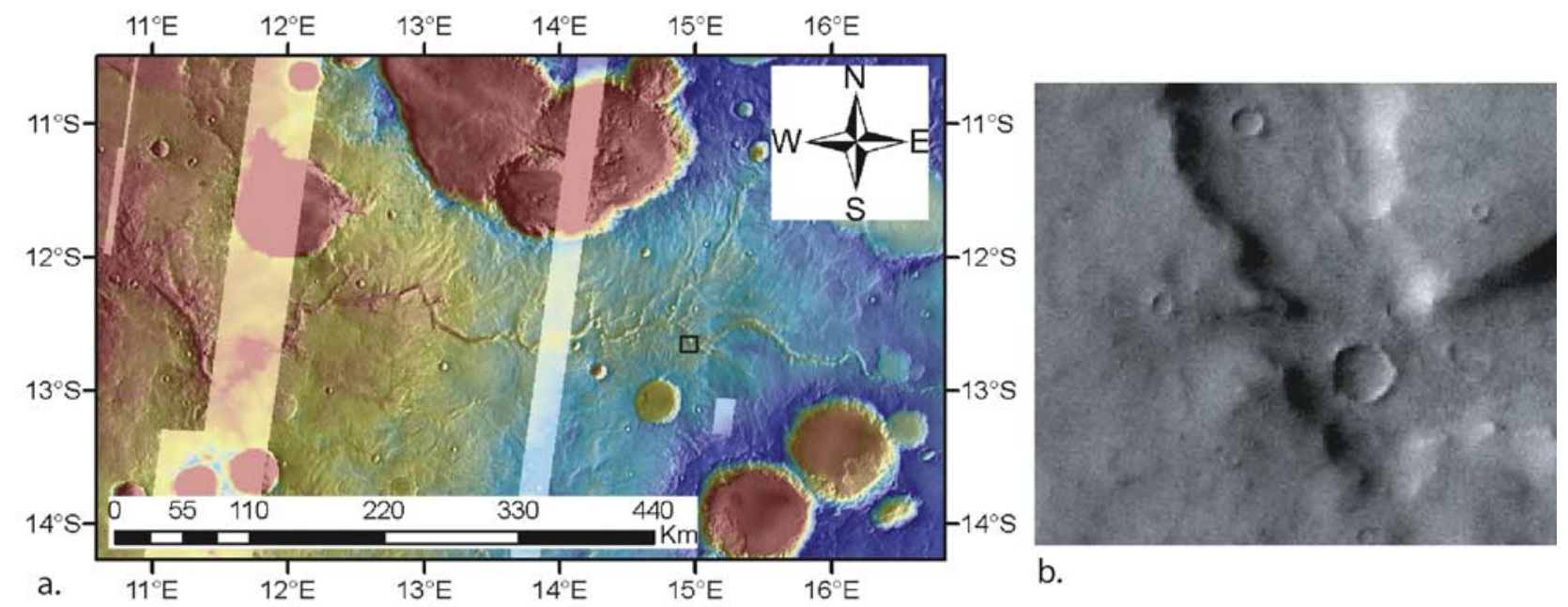

b.

Figure 8. (a) Context map of Evros Vallis. (b) V01648003 detail: $90^{\circ}$ bend in Evros Vallis, a structural control? 

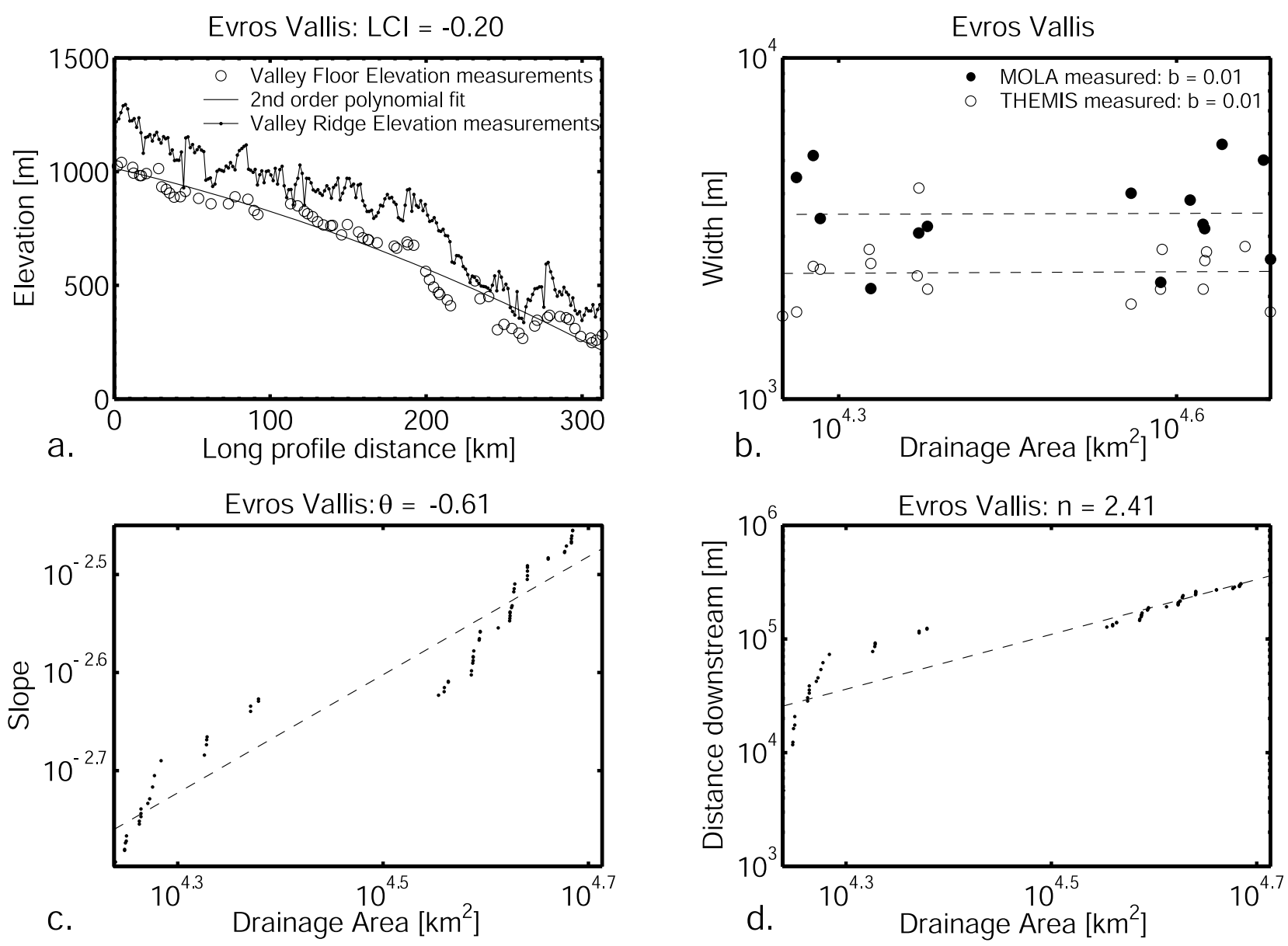

Figure 9. Topographic and scaling results for Evros Vallis ( $a-d$ are as in Figure 3). The first three segments in the distance downstream versus drainage area plot have a combined $\mathrm{n}$ value of 27.8 , compared with $\mathrm{n}=1.4$ for the last eight.

\subsection{Summary}

[42] The results of this study, summarized in Tables 2 and 3 , show that none of the Martian valleys satisfies all three scaling relations typical of terrestrial perennial channels, even those valleys approaching the dendritic morphology of terrestrial channel networks. Our analysis also shows that only Naktong Vallis has scaling characteristics consistent with arid to semiarid channels on Earth since, unlike the main tributary of Nanedi Valles, Naktong Vallis further satisfies Hack's law (although the "en echelon" structure of the data, discussed in section 5, is cause for concern). In contrast, Evros Vallis does not satisfy Hack's law, the scaling results are thus in curious contradiction with its apparent dendritic morphology. A plausible explanation is that the valley is not preserved in its entirety. By nondimensionalizing valley width, length and drainage area, we compare the different Martian valleys to each other, and with expected terrestrial perennial scaling (Figure 21). We observe that except for Naktong Vallis, Indus Vallis, Hrad Vallis, and the main tributary of Nanedi Valles, no large valley from this study displays a substantial range in drainage area increase (explaining their "clumping" at the right edge of Figure 21). Bahram Vallis is also the only valley of the ones studied with a concave longitudinal profile incised within convex topography. The sinuosity of Martian valleys, defined as the ratio of valley length to the straight-line valley length, ranges between 1.1 and 1.45 , values similar to terrestrial channels.

\section{Discussion}

[43] Given the morphological distinction of three different types of large valleys on Mars (section 1), we identified Bahram Vallis, Scamander Vallis, Tinto Vallis and Hrad Vallis as having negligible contributions from tributaries. With longitudinal profiles that follow local topography, and little downstream change in valley widths, the quantitative results from Scamander Vallis and Hrad Vallis are consistent with the erosional signatures of point source, ephemeral discharges. Such an origin for the discharges responsible for erosion is likewise consistent for Tinto Vallis, Nirgal Vallis and Nanedi Valles, although the tight meanders in the main valley of Nanedi Valles (described in section 4.6) remain enigmatic. Bahram Vallis' lack of contributing tributaries 


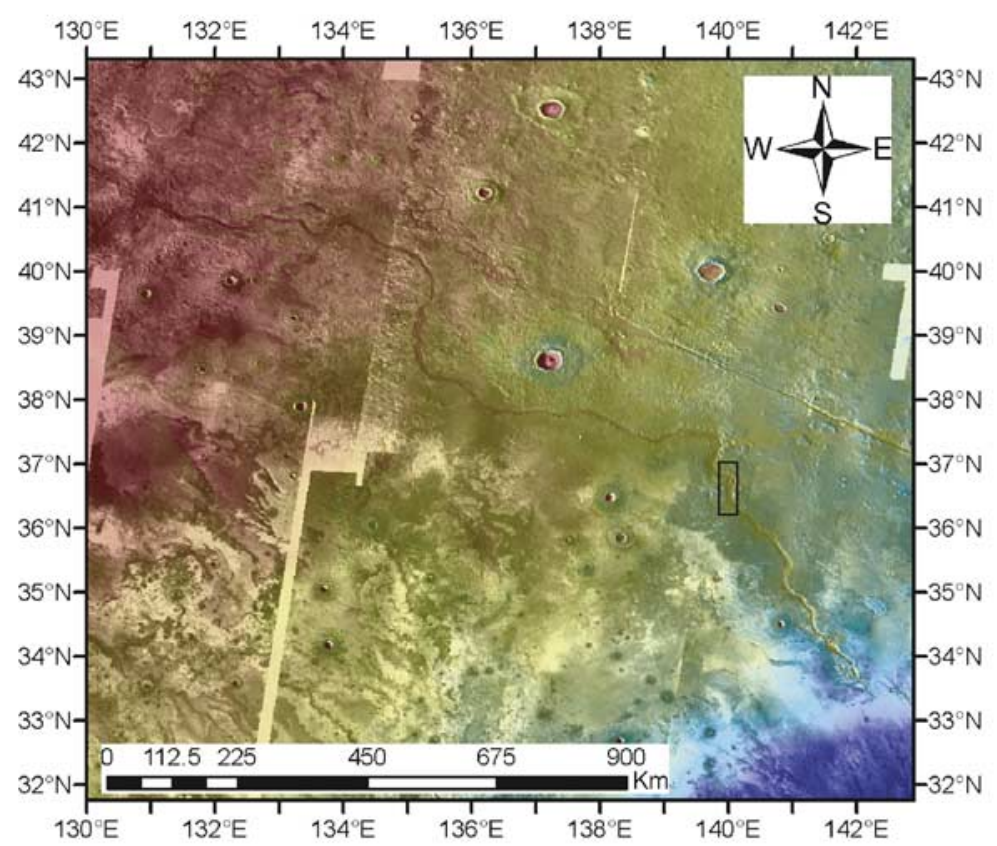

a.

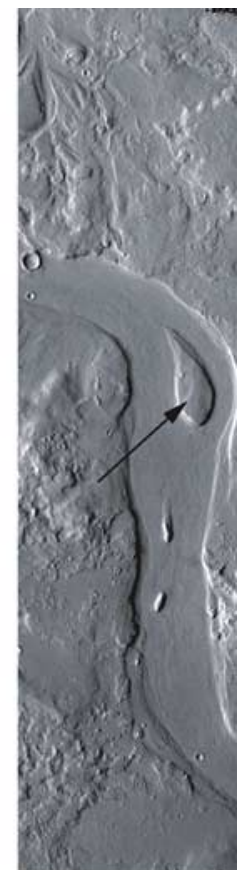

b.

Figure 10. (a) Context map of Hrad Vallis. (b) V10780005 detail: Surface flow evidence in Hrad Vallis.
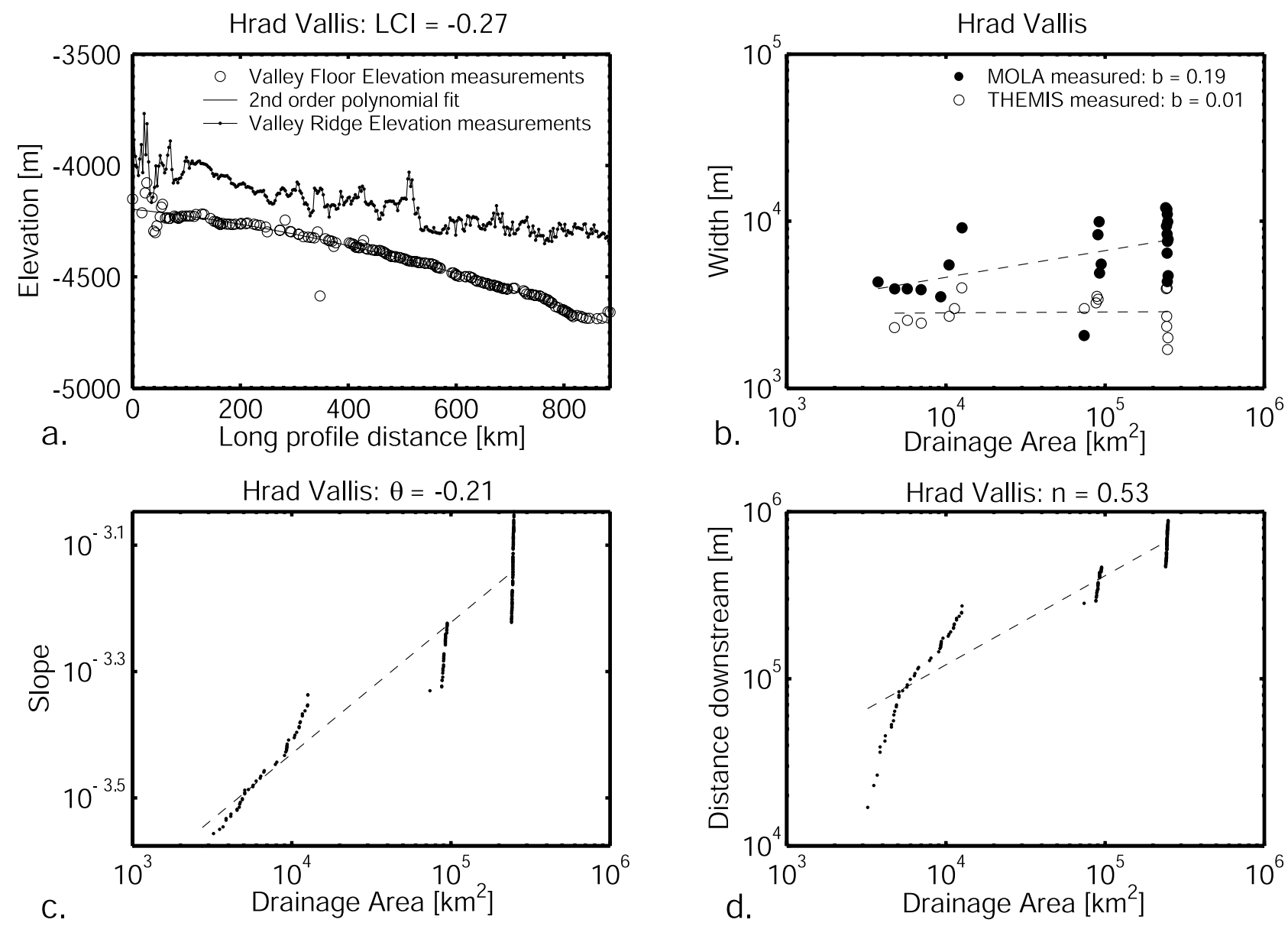

Figure 11. Topographic and scaling results for Hrad Vallis ( $a-d$ are as in Figure 3). 

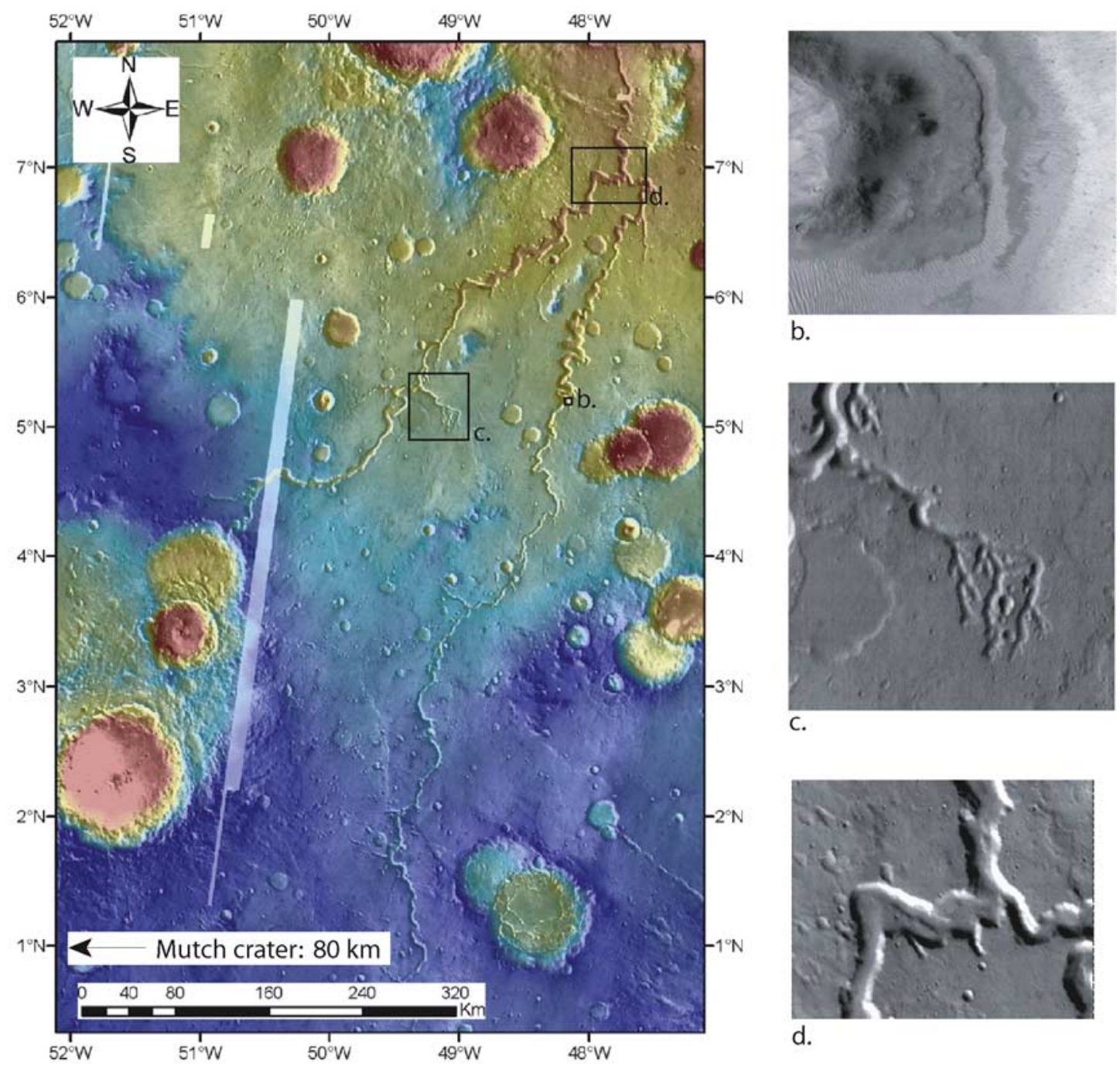

b.

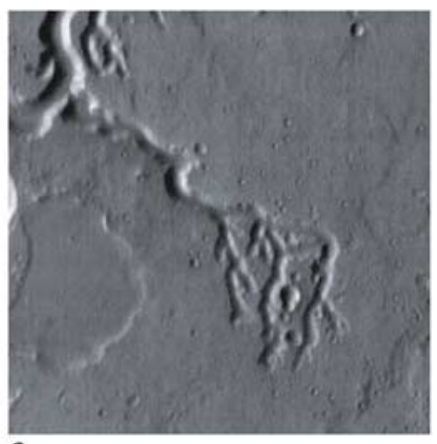

C.

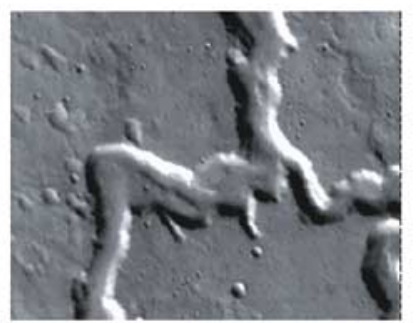

d.

a.

Figure 12. (a) Context map of Nanedi Valles. (b) E0501620 detail: The "channel" within Nanedi Vallis. (c) I10724003 detail: Third-order tributary head of Nanedi Valles' main tributary. (d) I16839013 detail: The merging of the 2 branches of Nanedi Valles. Note the lack of width increase after the merger.

and little downstream increase in drainage area suggests that most of the discharge that carved the valley was sourced upstream, possibly by overflow from Maja Valles to the south.

[44] The values of $\theta$ and $n$ are obtained by a power law fit to the data, consistent with equations (5) and (7). However, the data have an "en echelon" structure, unusual for terrestrial networks, but consistent with the observed low correlation coefficients $\mathrm{R}^{2}$. Each individual segment typically has a value of $\theta$ or $n$ an order of magnitude greater than the overall trend (Table 2). This segmentation further suggests that runoff is not provided from across a distributed drainage basin, and that another mechanism, likely of short duration from discrete source areas, gave rise to most of the valleys studied here, consistent with the morphological evidence and interpretation of large valleys by Carr and Malin [2000].
[45] We also identified Evros Vallis, Naktong Vallis, and Indus Vallis (all three incising Noachian terrain) as large valleys that are well dissected and that approach the dendritic morphology of terrestrial channel networks. However, detailed measurements of their downstream trends in width and slope reveal that they do not satisfy scaling relations of terrestrial perennial networks.

[46] Out of the 10 valleys studied here, only Naktong Vallis appears quantitatively (through scaling relationships) and observationally consistent with having been incised by meteoric water distributed across a drainage area, although it also displays an "en echelon" structure. Hence, two types of environments may be consistent with the morphology of Naktong Vallis: (1) an arid to semiarid climate (i.e., not "warm-wet") with infrequent and local precipitation events, resulting in ephemeral discharges, and (2) a very brief warmwet environment, with perennial discharges, but resulting in immature drainage systems. Knighton [1998] notes that 

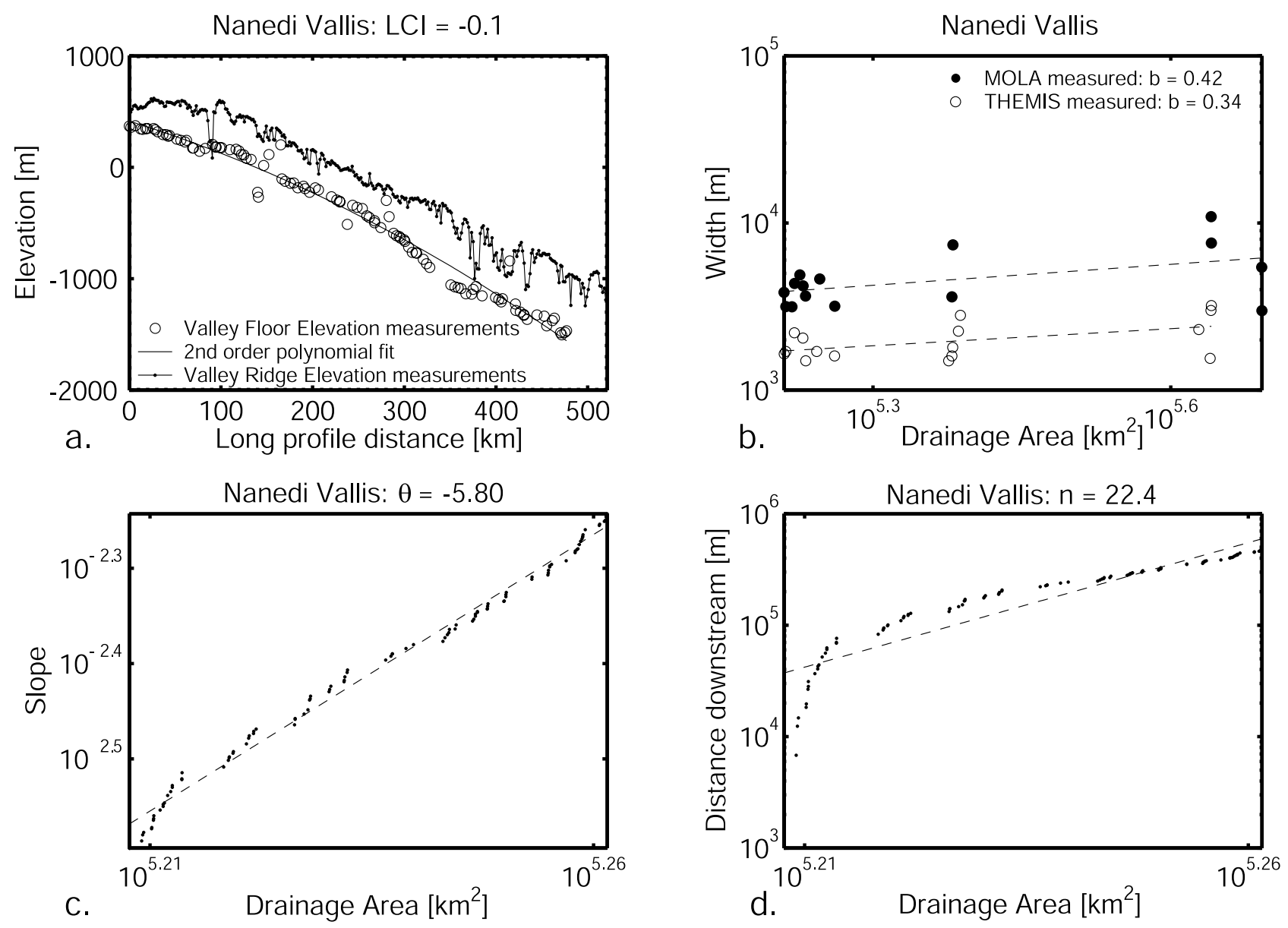

Figure 13. Topographic and scaling results of Nanedi Vallis main valley (a-d are as in Figure 3).

river profile gradients typically adjust to changes in perennial flow on the order $10^{2}-10^{4}$ years, constraining the limited duration for such a warm-wet environment. Since some fine-scale Noachian highland valley networks were likely formed by precipitation [e.g., Howard et al., 2005], and coupling this with our observations and those of others that they are physiographically immature [e.g., Irwin et al., 2005a], it is plausible to suggest that the atmosphere has never been adequate to sustain equilibrium channel and valley networks in the Noachian highlands, and the observed networks formed transiently. One such transient mechanism has been proposed by Segura et al. [2002], in discrete, impact-induced precipitation events.

[47] While we have seen that the entirety of Evros Vallis might not be preserved because of its failing to satisfy Hack's law, the fact that Indus Vallis (which satisfies Hack's law) also fails to satisfy the other expected terrestrial (perennial and ephemeral/immature) scaling relationships, despite its dendritic similarity to terrestrial networks supports arguments against a long duration warm-wet early Mars. Among the large valleys on Mars morphologically suggestive of terrestrial conditions, Indus Vallis and Naktong Vallis are the best preserved. Had large amounts of water persisted on the surface of early Mars, hydrological cycling water through the atmosphere would have been expected, resulting in incision of substantial valleys with terrestrial-like scaling. Although, we find no direct evidence of this in our analyses, our observations are consistent with environmental conditions allowing transient, shallow lakes [Squyres et al., 2004].

[48] On the basis of these observations, the studied Martian valleys support the notion that if an environment capable of sustaining equilibrium channel and valley networks existed in the Noachian [e.g., Craddock and Howard, 2002], such an environment was transient and/or waned rapidly. Had such conditions extended well into the Hesperian, signatures in the morphology of the large valleys would have been expected, contrary to our observations. Instead, our analysis shows morphological similarities to arid terrestrial networks, or a very short warm-wet climate. This conclusion is independently supported by the work of Elwood-Madden et al. [2004], which found that the occurrence of jarosite, along with unweathered basalt at the rover Opportunity landing site at Meridiani Planum (3-4 Ga) [Squyres and Knoll, 2005] required liquid water only episodically.

[49] We do, however, recognize our limited sample size. Pending the availability of High Resolution Stereo Camera (HRSC) [Neukum and Jaumann, 2004] and High Resolution Image Spectrometer (HiRISE) [McEwen et al., 2007] DEM's, future quantitative geomorphic studies on Martian 

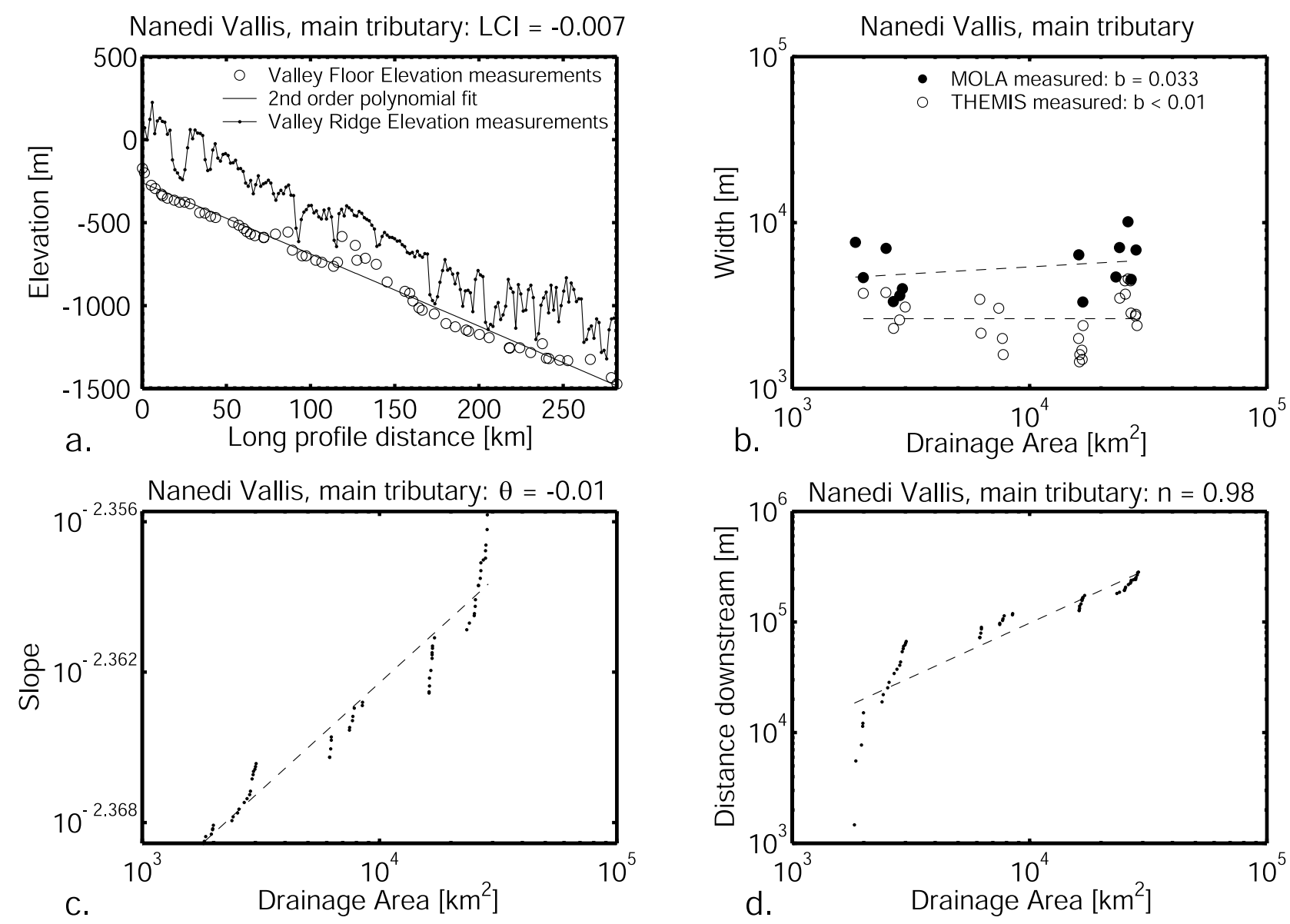

Figure 14. Topographic and scaling results of Nanedi Vallis main tributary (a-d are as in Figure 3). The first three segments in distance downstream versus drainage area plot have a combined $n$ value of 5.1, compared with $\mathrm{n}=0.7$ for the last four.

valley networks too small to be resolvable using MOLA would complement the analyses presented here, and further illuminate the history of water on Mars.

\section{Conclusion}

[50] We identified 10 large valley networks on Mars as resolvable using topographic data from the Mars Orbiter Laser Altimeter, and classified them in 3 groups, based on their appearance. We classified them as either (1) valleys originating in point sources with negligible contributions from tributaries, (2) valleys that are very poorly dissected with a few large tributaries separated by long uninterrupted trunks, or (3) well-dissected valleys that approach the dendritic morphology typical of terrestrial networks. We then quantified their morphology using width-area, slopearea, and distance-area (Hack's law) scaling relationships, and assessed their downstream variation in valley widths and bed curvature, two robust fluvial metrics for terrestrial channel networks. We found that none satisfy scaling relationships for terrestrial perennial channels, not even the ones classified as having a morphology approaching terrestrial networks, which are Noachian in age. On Mars, the width-area scaling exponent $b$ ranged from $-0.7-4.7$; the slope-area scaling exponent $\theta$ ranged from $-25.6-5.5$; and Hack's exponent $\mathrm{n}$ ranged from 0.47 to 19.2. Our results on valleys that are morphologically similar to terrestrial networks suggest their formation in either an arid, or a very short warm-wet climate. The scaling results for the other large valleys are consistent with their observed morphology, in having a point source and ephemeral discharge responsible for their incision. We further posit that the putative warm-wet period did not last much beyond the early Noachian if it did indeed exist. Consequently, terrestrial ephemeral and immature channel morphology and dam-break spillways provide informative analogs for the study of the large Martian valleys.

\section{Appendix A}

[51] The different accelerations due to gravity between Earth $\left(9.81 \mathrm{~m} / \mathrm{s}^{2}\right)$ and Mars $\left(3.72 \mathrm{~m} / \mathrm{s}^{2}\right)$ will not alter the trend of the width-area curve, and thus not alter the exponent $\mathrm{b}$ ( or $\theta$ and $\mathrm{n}$ ), but will alter the $\mathrm{y}$-intercept. This is addressed quantitatively here to compare expected measurements of channel widths on Earth with those measured on Mars, given identical hydraulic parameters.

[52] We start with the modified Manning's equation, as described by Gioia and Bombardelli [2002], which is derived from turbulence theory and corrects for the dimen- 

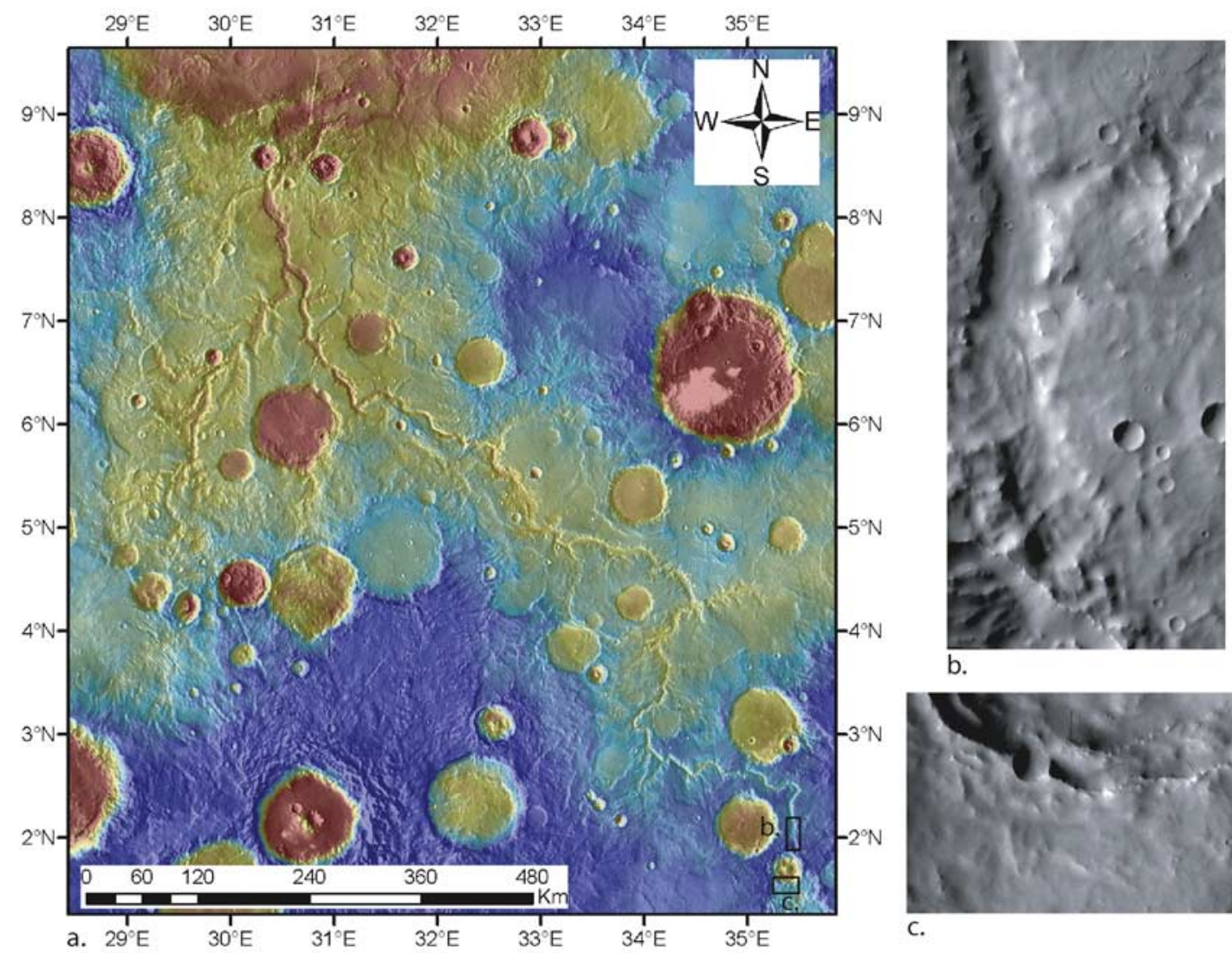

b.

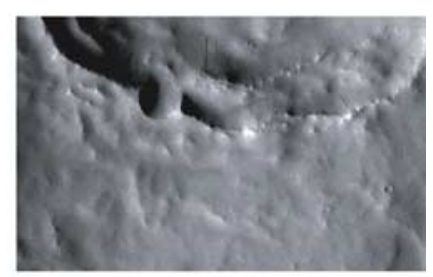

c.

Figure 15. (a) Context map of Naktong Vallis. (b) V11370014 detail: The source of Naktong Vallis, incising impact ejecta. (c) V17198011 detail: The south rim of the Naktong "source crater." Note the lack of incision. 

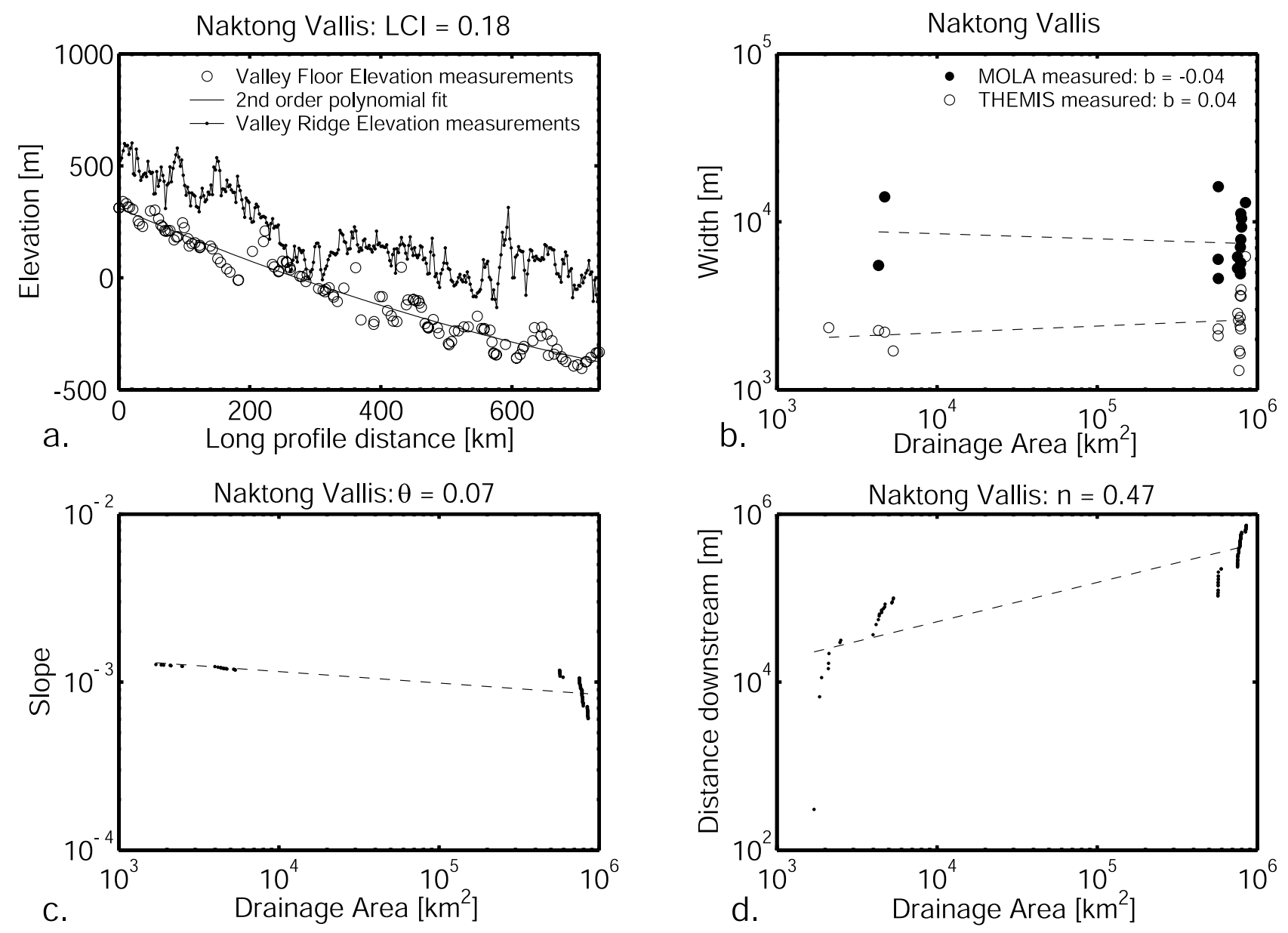

Figure 16. Topographic and scaling results for Naktong Vallis ( $\mathrm{a}-\mathrm{d}$ are as in Figure 3). 


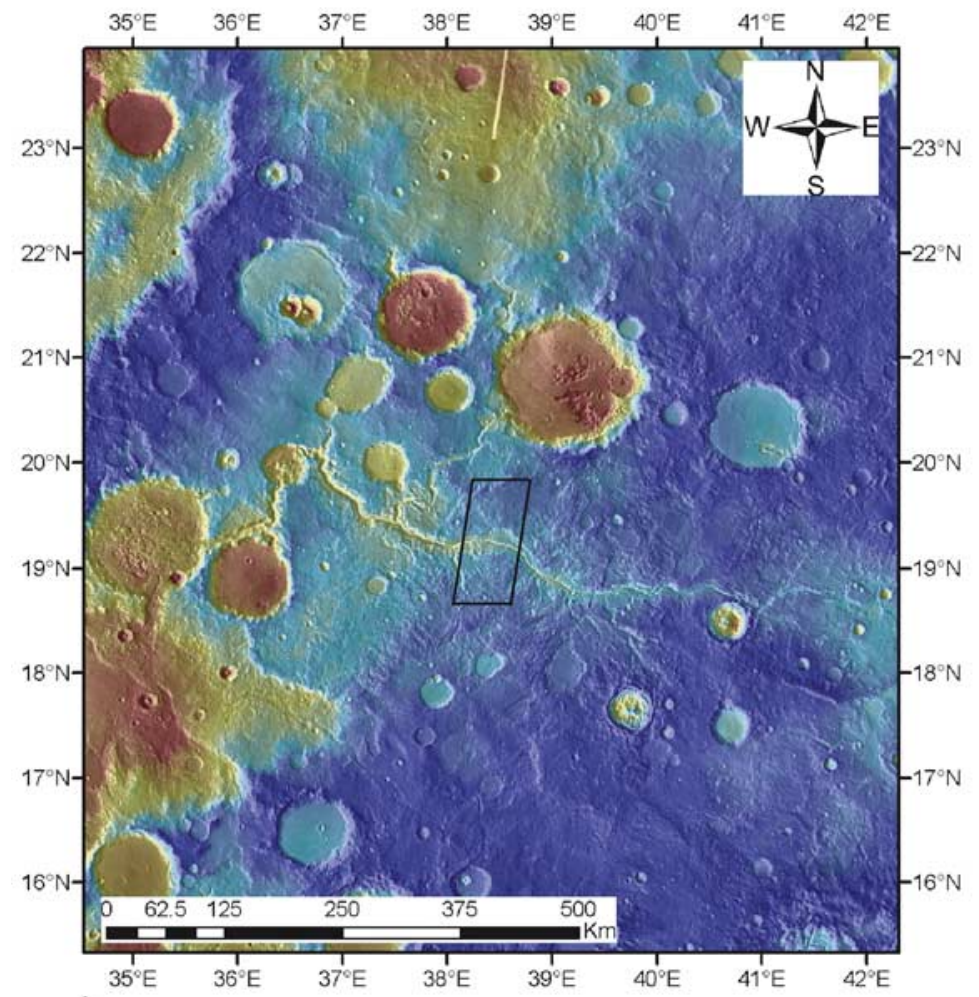

a.

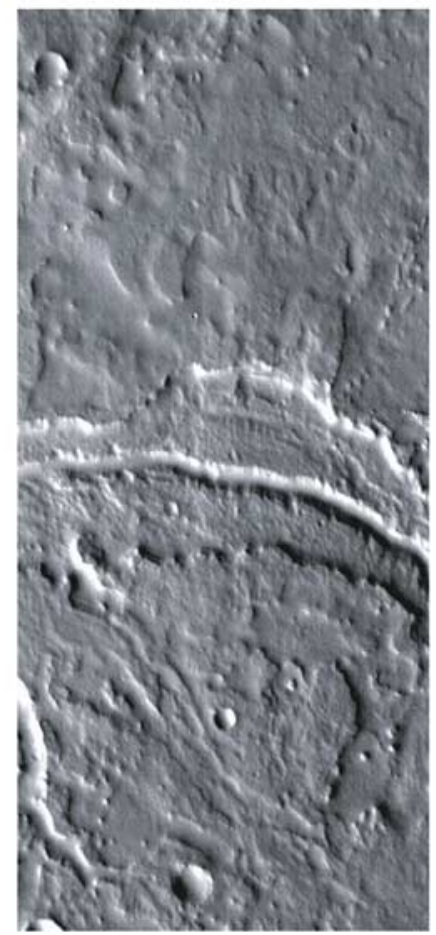

b.

Figure 17. (a) Context map of Indus Vallis. (b) I17797018 detail: Incised channel inset within Indus Vallis. 

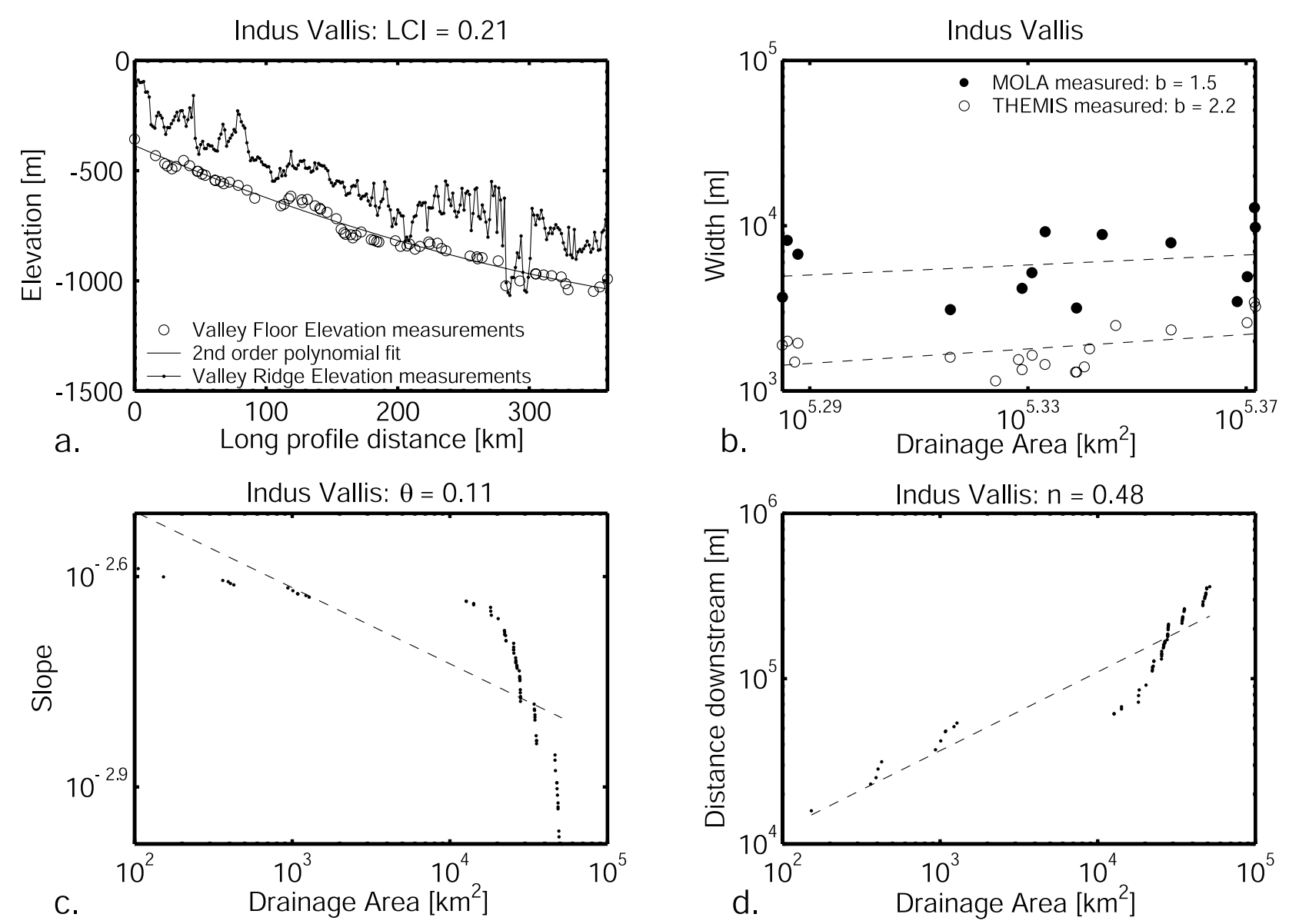

Figure 18. Topographic and scaling results for Indus Vallis (a-d are as in Figure 3 ). The two obvious trends in $\theta$ (and corresponding $\mathrm{n}$ ) are listed as the parenthetical values of $\theta$ (and $\mathrm{n}$ ) in Table 2. 

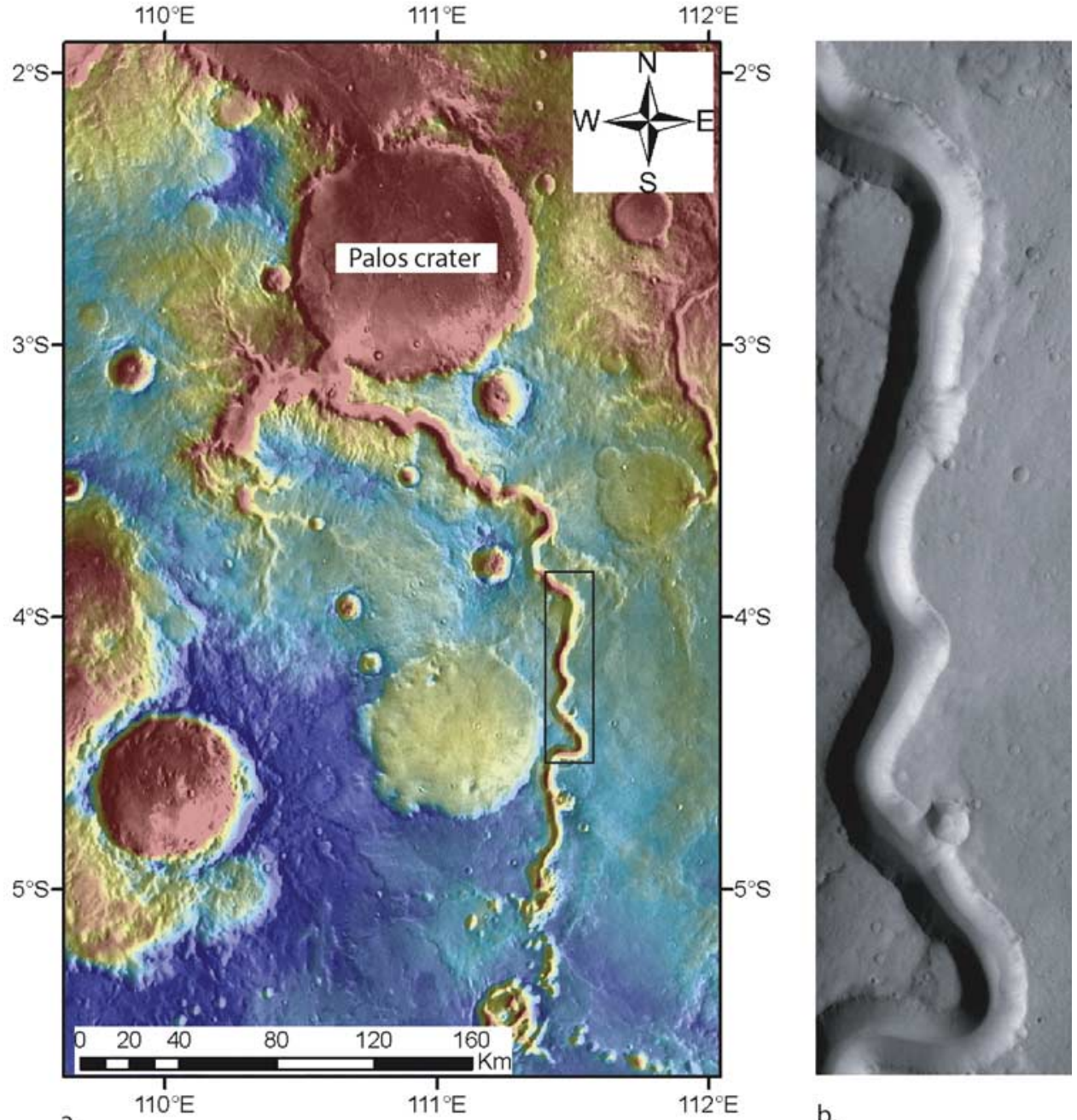

a.

Figure 19. (a) Context map of Tinto Vallis. (b) V17708002 detail: Tinto Vallis. 

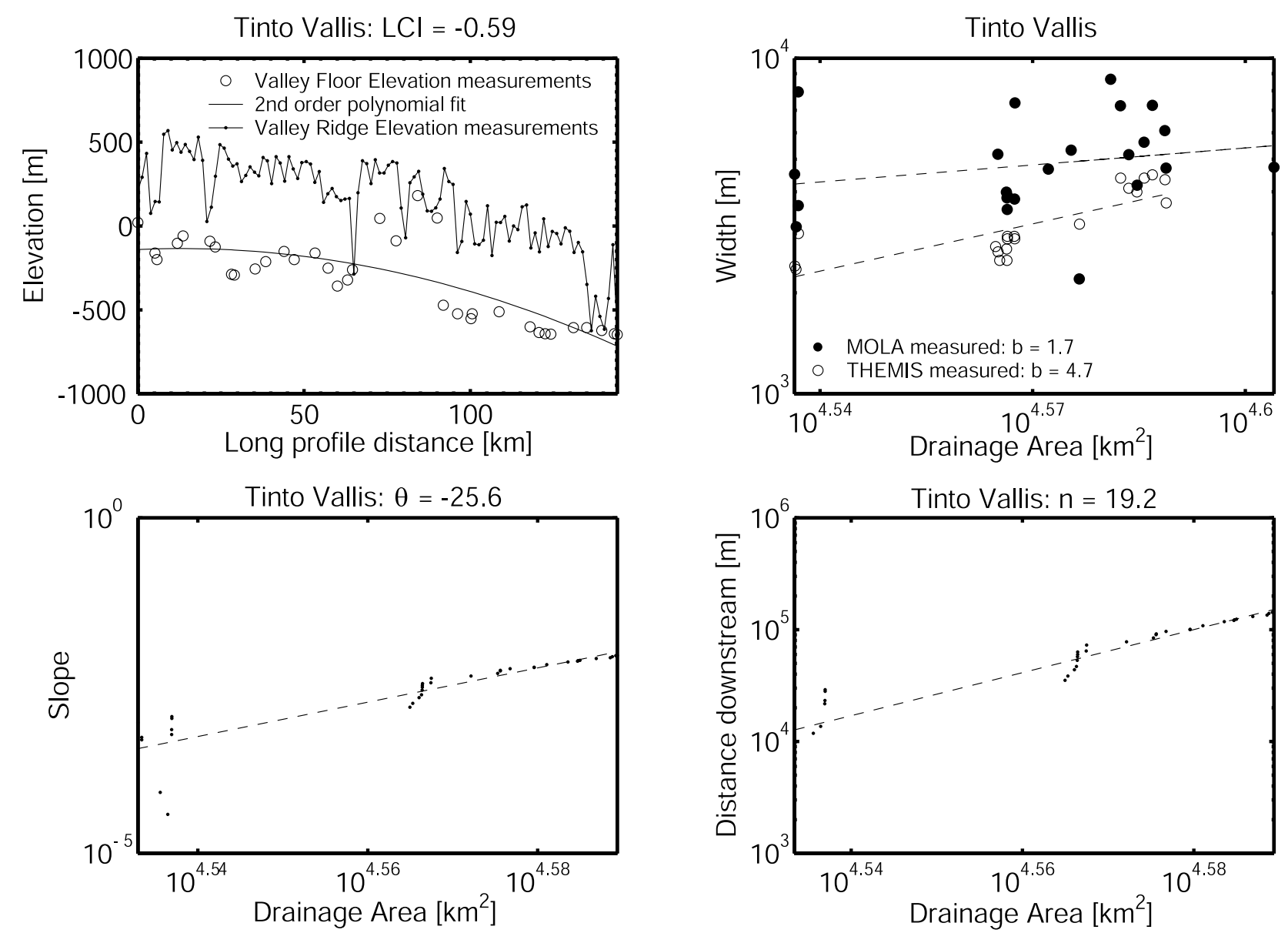

Figure 20. Topographic and scaling results for Tinto Vallis ( $-\mathrm{d}$ are as in Figure 3). 

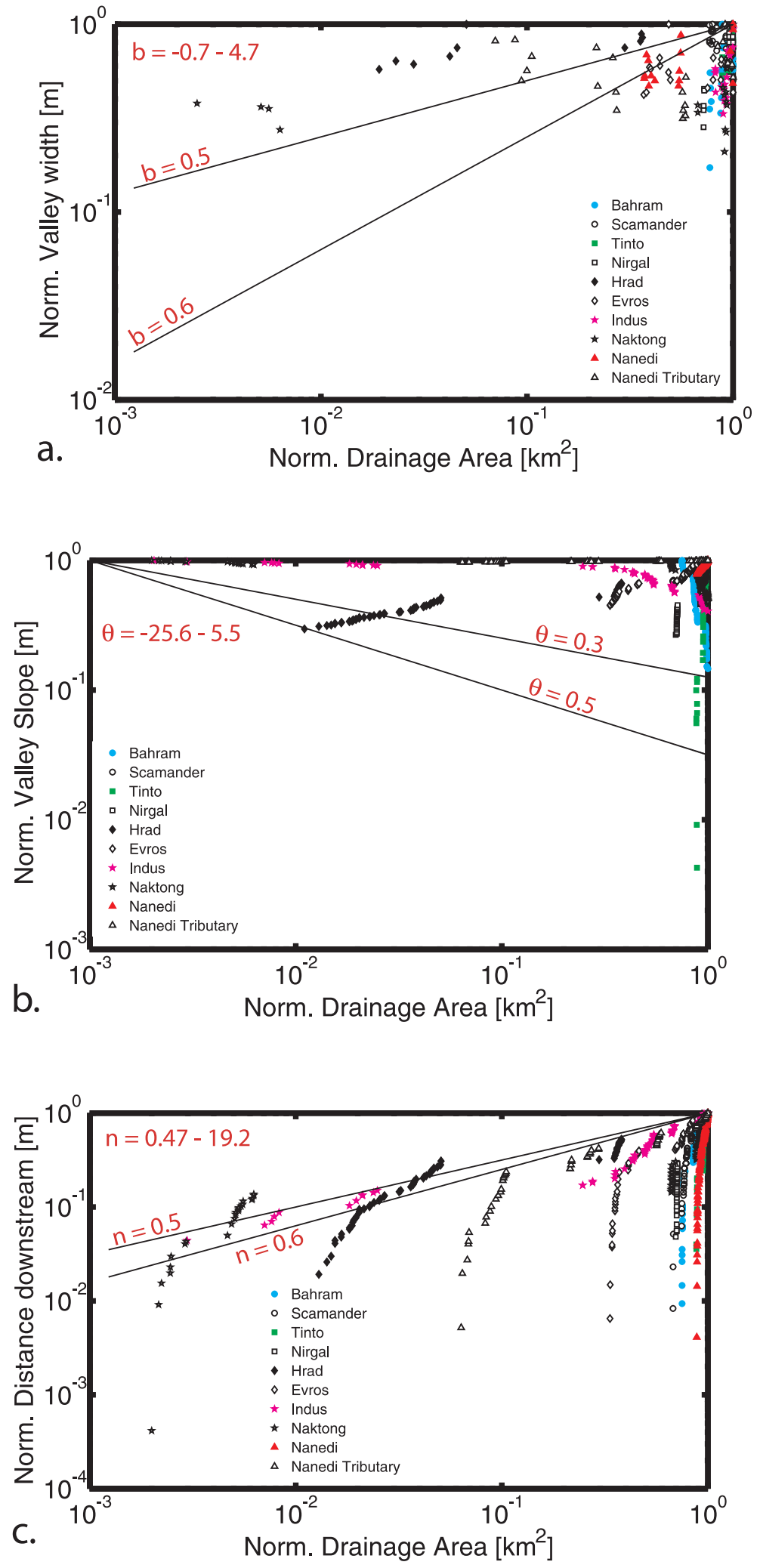

Figure 21. Normalized Martian scaling results compared with terrestrial perennial expectations (between solid lines). (a) Normalized valley width versus normalized drainage area. (b) Normalized slope versus normalized drainage area. (c) Normalized valley lengths versus drainage area (Hack's law). 


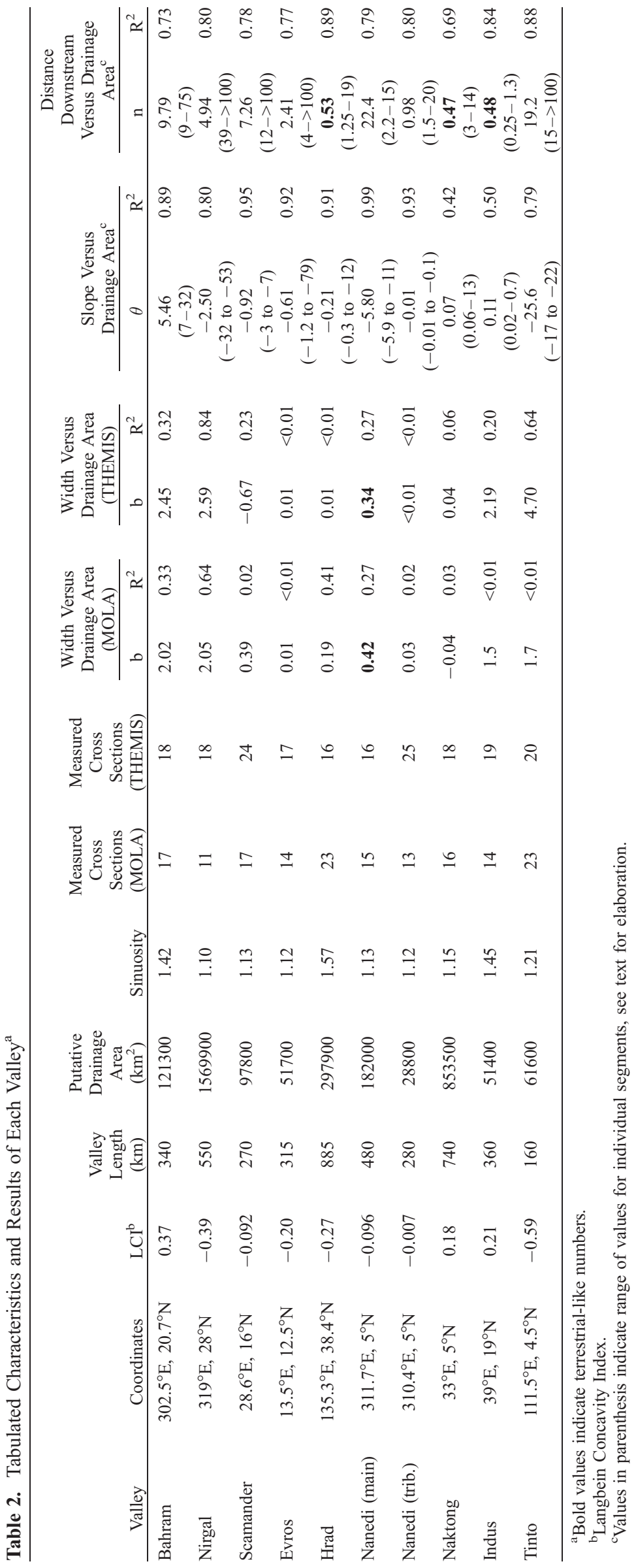


Table 3. Summary of Results

\begin{tabular}{|c|c|c|c|}
\hline & $\mathrm{b} \leq 0.05$ & $\mathrm{~b} \sim$ Terrestrial (Perennial) & $b>2$ \\
\hline $\begin{array}{l}|\theta|<0.2 \\
\quad \text { (quasi-linear) }\end{array}$ & $\begin{array}{l}\text { Nanedi Vallis (tributary) } \\
\text { Naktong Vallis } \\
\text { a } \\
\text { terrestrial semiarid to arid } \\
\text { channels would map here }\end{array}$ & & Indus Vallis $^{\mathrm{a}}$ \\
\hline $\begin{array}{l}\theta<0 \\
\quad \text { (convex) }\end{array}$ & $\begin{array}{c}\text { Scamander Vallis } \\
\text { Evros Vallis, Hrad Vallis }{ }^{\mathrm{a}}\end{array}$ & Nanedi Vallis (main) & Nirgal Vallis Tinto Vallis \\
\hline $\begin{aligned} \theta & >0.2 \\
& (\text { concave) }\end{aligned}$ & & $\begin{array}{l}\text { terrestrial perennial to arid } \\
\text { channels would map here }\end{array}$ & Bahram Vallis \\
\hline
\end{tabular}

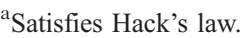

sional inconsistencies in the traditional Manning's equation [Gioia and Bombardelli, 2002; Kleinhans, 2005; Wilson et al., 2004]:

$$
U=k(R / r)^{1 / 6}(R g S)^{1 / 2},
$$

where $\mathrm{U}$ is the fluid velocity, $\mathrm{k}$ is a dimensionless constant, $\mathrm{R}$ is the hydraulic radius, $\mathrm{r}$ is the characteristic size of the bed material, and $\mathrm{S}$ is the slope. In a manner analogous to Finnegan et al. [2005] we define

$$
\alpha={ }^{W} / D,
$$

where $\mathrm{W}$ represents the channel width and $\mathrm{D}$ the channel depth. We thus impose the constraint of constant width-todepth ratio to the assumption of rectangular channel. The hydraulic radius can thus be rewritten in terms of $\mathrm{W}$ and $\alpha$ as

$$
R=W /(\alpha+2) \text {. }
$$

Substituting (A3) into (A1) and rearranging, one obtains

$$
U=k r^{-1 / 6}(\alpha+2)^{-2 / 3} g^{1 / 2} S^{1 / 2} W^{2 / 3} .
$$

Because $\mathrm{Q}=\mathrm{UA}$, where $\mathrm{Q}$ is the discharge and A the crosssectional area, (with $\mathrm{A}$ expressed as $\mathrm{A}=\mathrm{WD}=\mathrm{W}^{2} / \alpha$ ), one can write

$$
Q=k r^{-1 / 6}(\alpha+2)^{-2 / 3} g^{1 / 2} S^{1 / 2} W^{8 / 3} \alpha^{-1} .
$$

And thus solving for $\mathrm{W}$

$$
W=Q^{3 / 8} k^{-3 / 8} r^{1 / 16}\left(\alpha(\alpha+2)^{2 / 3}\right)^{3 / 8} g^{-3 / 16} S^{-3 / 16} .
$$

Taking all variables to be identical for two channels on Earth and Mars, except for the accelerations due to gravity $\left(9.81 \mathrm{~m} / \mathrm{s}^{2}\right.$ and $3.72 \mathrm{~m} / \mathrm{s}^{2}$, respectively), yields

$$
W_{\text {Earth }}=0.83 \cdot W_{\text {Mars }} \text { or } W_{\text {Mars }}=1.20 \cdot W_{\text {Earth }} .
$$

[53] Acknowledgments. We thank Dyan Padagas for assisting in some of the data collection. The manuscript benefited from insightful reviews by Alan Howard, Virginia Gulick, and an anonymous reviewer.

\section{References}

Aharonson, O., M. T. Zuber, D. H. Rothman, N. Schorghofer, and K. X. Whipple (2002), Drainage basins and channel incision on Mars, Proc. Natl. Acad. Sci. U. S. A., 99(4), 1780-1783, doi:10.1073/pnas.261704198.

Ansan, V., and N. Mangold (2006), New observations of Warrego Valles, Mars: Evidence for precipitation and surface runoff, Planet. Space Sci., 54(3), 219-242, doi:10.1016/j.pss.2005.12.009.

Baker, V. R., and J. B. Partridge (1986), Small Martian valleys: Pristine and degraded morphology, J. Geophys. Res., 91(B3), 3561-3572, doi:10.1029/JB091iB03p03561.

Baker, V. R., M. H. Carr, V. C. Gulick, C. R. Williams, and M. S. Marley (1992), Channels and valley networks, in Mars, edited by H. H. Kieffer et al., pp. 493-522, Univ. of Ariz. Press, Tucson.

Bhattacharya, J. P., T. H. D. Payenberg, S. C. Lang, and M. Bourke (2005), Dynamic river channels suggest a long-lived Noachian crater lake on Mars, Geophys. Res. Lett., 32(10), L10201, doi:10.1029/2005GL022747.

Brakenridge, G. R., H. E. Newsom, and V. R. Baker (1985), Ancient hot springs on Mars: Origins and paleoenvironmental significance of small Martian valleys, Geology, 13(12), 859-862, doi:10.1130/00917613(1985)13<859:AHSOMO $>2.0 . C O ; 2$

Bull, L., and M. Kirkby (2002), Dryland Rivers, Hydrology and Geomorphology of Semi-Arid Channels, John Wiley, New York.

Carr, M. H. (1986), Mars: A water-rich planet, Icarus, 68(2), 187-216, doi:10.1016/0019-1035(86)90019-9.

Carr, M. H. (1995), The Martian drainage system and the origin of valley networks and fretted channels, J. Geophys. Res., 100(E4), 7479-7507, doi:10.1029/95JE00260.

Carr, M. H. (1996), Water on Mars, 229 pp., Oxford Univ. Press, New York.

Carr, M. H., and F. C. Chuang (1997), Martian drainage densities, J. Geophys. Res., 102(E4), 9145-9152, doi:10.1029/97JE00113.

Carr, M. H., and J. W. Head (2003), Basal melting of snow on early Mars: A possible origin of some valley networks, Geophys. Res. Lett., 30(24), 2245, doi:10.1029/2003GL018575.

Carr, M. H., and M. C. Malin (2000), Meter-scale characteristics of Martian channels and valleys, Icarus, 146(2), 366-386, doi:10.1006/ icar.2000.6428

Christensen, P. R., et al. (2004), The Thermal Emission Imaging System (THEMIS) for the Mars 2001 Odyssey Mission, Space Sci. Rev., 110, $85-130$

Coleman, N. M. (2003), Aqueous flows carved the outflow channels on Mars, J. Geophys. Res., 108(E5), 5039, doi:10.1029/2002JE001940.

Craddock, R. A., and A. D. Howard (2002), The case for rainfall on a warm, wet early Mars, J. Geophys. Res., 107(E11), 5111, doi:10.1029/ 2001JE001505

Elwood-Madden, M. E., R. J. Bodnar, and J. D. Rimstidt (2004), Jarosite as an indicator of water-limited chemical weathering on Mars, Nature, 431(7010), 821-823, doi:10.1038/nature02971.

Environmental Systems and Research Institute (1997), Understanding GIS Redlands, Calif.

Fassett, C. I., and J. W. Head (2008), The timing of Martian valley network activity: Constraints from buffered crater counting, Icarus, 195(1), 6189, doi:10.1016/j.icarus.2007.12.009.

Finnegan, N. J., G. Roe, D. R. Montgomery, and B. Hallet (2005), Controls on the channel width of rivers: Implications for modeling fluvial incision of bedrock, Geology, 33(3), 229-232, doi:10.1130/G21171.1.

Gilbert, G. K. (1877), Report on Geology of the Henry Mountains, 160 pp., U.S. Geol. Surv. of the Rocky Mt. Reg., Washington, D. C.

Gioia, G., and F. A. Bombardelli (2002), Scaling and similarity in rough channel flows, Phys. Rev. Lett., 88(1), 014501, doi:10.1103/PhysRevLett. 88.014501 .

Grant, J. A., R. P. Irwin, J. P. Grotzinger, R. E. Milliken, L. L. Tornabene, A. S. McEwen, C. M. Weitz, S. W. Squyres, T. D. Glotch, and B. J. Thomson (2008), HiRISE imaging of impact megabreccia and sub-meter 
aqueous strata in Holden Crater, Mars, Geology, 36(3), 195-198, doi:10.1130/G24340A.1.

Gulick, V. C. (2001), Origin of the valley networks on Mars: A hydrological perspective, Geomorphology, 37(3-4), 241-268, doi:10.1016/ S0169-555X(00)00086-6.

Gulick, V. C., and V. R. Baker (1989), Fluvial valleys and Martian paleoclimates, Nature, 341(6242), 514-516, doi:10.1038/341514a0.

Gulick, V. C., D. Tyler, and C. P. McKay (1997), Episodic ocean-induced $\mathrm{CO} 2$ greenhouse on Mars: Implications for fluvial valley formation, Icarus, 130(1), 68-86, doi:10.1006/icar.1997.5802.

Hack, J. T. (1957), Studies of longitudinal stream profiles in Virginia and Maryland, U.S. Geol. Surv. Prof. Pap., 294-B, 45-97.

Harrison, K. P., and R. E. Grimm (2005), Groundwater-controlled valley networks and the decline of surface runoff on early Mars, J. Geophys. Res., 110(E12), E12S16, doi:10.1029/2005JE002455.

Hartmann, W. K. (2005), Martian cratering 8: Isochron refinement and the chronology of Mars, Icarus, 174(2), 294-320, doi:10.1016/ j.icarus.2004.11.023.

Hartmann, W. K., and G. Neukum (2001), Cratering chronology and the evolution of Mars, Space Sci. Rev., 96(1-4), 165-194, doi:10.1023/ A:1011945222010.

Hoffman, N. (2000), White Mars: A new model for Mars' surface and atmosphere based on CO2, Icarus, 146(2), 326-342, doi:10.1006/ icar 2000.6398 .

Hooke, J., and J. Mant (2002), Morpho-dynamics of ephemeral streams, in Dryland Rivers, Hydrology and Geomorphology of Semi-Arid Channels, edited by L. Bull and M. Kirkby, pp. 173-204, John Wiley, New York.

Horton, R. E. (1945), Erosional development of streams and their drainage basins: Hydrophysical approach to quantitative morphology, Geol. Soc. Am. Bull., 56, 275-370, doi:10.1130/0016-7606(1945)56[275:EDOSAT] 2.0.CO;2.

Howard, A. D. (1994), A detachment-limited model of drainage basin evolution, Water Resour. Res., 30(7), 2261-2285, doi:10.1029/94WR00757.

Howard, A. D. (2007), Simulating the development of Martian highland landscapes through the interaction of impact cratering, fluvial erosion, and variable hydrologic forcing, Geomorphology, 91, 332-363, doi:10.1016/j.geomorph.2007.04.017.

Howard, A. D., and G. Kerby (1983), Channel changes in Badlands, Geol. Soc. Am. Bull., 94, 739-752, doi:10.1130/0016-7606(1983)94 $<739$ : $\mathrm{CCIB}>2.0 . \mathrm{CO} ; 2$

Howard, A. D., J. M. Moore, and R. P. Irwin (2005), An intense terminal epoch of widespread fluvial activity on early Mars: 1. Valley network incision and associated deposits, J. Geophys. Res., 110(E12), E12S14, doi:10.1029/2005JE002459.

Hynek, B. M., and R. J. Phillips (2003), New data reveal mature, integrated drainage systems on Mars indicative of past precipitation, Geology, 31(9), 757-760, doi:10.1130/G19607.1.

Irwin, R. P., R. A. Craddock, and A. D. Howard (2005a), Interior channels in Martian valley networks: Discharge and runoff production, Geology, 33(6), 489-492, doi:10.1130/G21333.1.

Irwin, R. P., A. D. Howard, R. A. Craddock, and J. M. Moore (2005b), An intense terminal epoch of widespread fluvial activity on early Mars: 2. Increased runoff and paleolake development, J. Geophys. Res., 110(E12), E12S15, doi:10.1029/2005JE002460

Jaumann, R., et al. (2005), Interior channels in Martian valleys: Constraints on fluvial erosion by measurements of the Mars Express High Resolution Stereo Camera, Geophys. Res. Lett., 32(16), L16203, doi:10.1029/ 2005GL023415.

Kehew, A., and M. Lord (1987), Glacial-lake outbursts along the midcontinent margins of the Laurentide ice-sheet, in Catastrophic Flooding, edited by L. Mayer and D. Nash, pp. 95-120, Allen and Unwin, Boston.

Kirchner, J. W. (1993), Statistical inevitability of Horton laws and the apparent randomness of stream channel networks, Geology, 21(7), 591-594, doi:10.1130/0091-7613(1993)021<0591:SIOHSL $>2.3$.CO;2.

Kleinhans, M. G. (2005), Flow discharge and sediment transport models for estimating a minimum timescale of hydrological activity and channel and delta formation on Mars, J. Geophys. Res., 110(E12), E12003, doi:10.1029/2005JE002521.

Knighton, D. (1998), Fluvial Forms and Processes, Arnold, London.

Komar, P. (1980), Comparisons of the hydraulics of water flows in Martian outflow channels with flows of similar scale on Earth, Icarus, 42(3), 317-329, doi:10.1016/0019-1035(80)90097-4

Kraal, E. R., M. van Dijk, G. Postma, and M. G. Kleinhans (2008), Martian stepped-delta formation by rapid water release, Nature, 451(7181), $973-$ 976, doi:10.1038/nature06615.

Langbein, W. B. (1964), Profiles of rivers of uniform discharge, U.S. Geol. Surv. Prof. Pap., 501-B, 119-122.

Leopold, L., and T. Maddock (1953), The hydraulic geometry of stream channels and some physiographic implications, U.S. Geol. Surv. Prof. Pap., 252, 57 pp.
Luo, W. (2002), Hypsometric analysis of Margaritifer Sinus and origin of valley networks, J. Geophys. Res., 107(E10), 5071, doi:10.1029/ 2001JE001500

Luo, W., and T. F. Stepinski (2006), Topographically derived maps of valley networks and drainage density in the Mare Tyrrhenum quadrangle on Mars, Geophys. Res. Lett., 33(18), L18202, doi:10.1029/ 2006GL027346.

Mabbutt, J. A. (1977), Desert Landforms, Aust. Natl. Univ. Press, Canberra, Australia.

Mackin, J. H. (1948), Concept of the graded river, Geol. Soc. Am. Bull., 59 463-512, doi:10.1130/0016-7606(1948)59[463:COTGR]2.0.CO;2.

Malin, M. C., and M. H. Carr (1999), Groundwater formation of Martian valleys, Nature, 397(6720), 589-591, doi:10.1038/17551.

Malin, M. C., and K. S. Edgett (2000), Evidence for recent groundwater seepage and surface runoff on Mars, Science, 288(5475), 2330-2335, doi:10.1126/science.288.5475.2330.

Malin, M. C., and K. S. Edgett (2003), Evidence for persistent flow and aqueous sedimentation on early Mars, Science, 302(5652), 1931-1934, doi:10.1126/science. 1090544

Mangold, N., and V. Ansan (2006), Detailed study of an hydrological system of valleys, a delta and lakes in the Southwest Thaumasia region, Mars, Icarus, 180(1), 75-87, doi:10.1016/j.icarus.2005.08.017.

Mangold, N., C. Quantin, V. Ansan, C. Delacourt, and P. Allemand (2004), Evidence for precipitation on Mars from dendritic valleys in the valles marineris area, Science, 305(5680), 78-81, doi:10.1126/science. 1097549 .

Mars Channel Working Group (1983), Channels and valleys on Mars, Geol. Soc. Am. Bull., 94, 1035-1054, doi:10.1130/0016-7606(1983) 94<1035:CAVOM>2.0.CO;2.

McEwen, A. S., et al. (2007), Mars Reconnaissance Orbiter's High Resolution Imaging Science Experiment (HiRISE), J. Geophys. Res., 112(E5), E05S02, doi:10.1029/2005JE002605

Merritt, D. M., and E. E. Wohl (2003), Downstream hydraulic geometry and channel adjustment during a flood along an ephemeral, arid-region drainage, Geomorphology, 52(3-4), 165-180.

Montgomery, D. R., and W. E. Dietrich (1992), Channel initiation and the problem of landscape scale, Science, 255(5046), 826-830, doi:10.1126/ science. 255.5046 .826

Montgomery, D. R., and K. B. Gran (2001), Downstream variations in the width of bedrock channels, Water Resour. Res., 37(6), 1841-1846, doi:10.1029/2000WR900393.

Montgomery, D. R., and J. Lopez-Blanco (2003), Post-Oligocene river incision, southern Sierra Madre Occidental, Mexico, Geomorphology, 55(1-4), 235-247, doi:10.1016/S0169-555X(03)00142-9.

Mueller, J. (1973), Re-evaluation of the relationship of master streams and drainage basins: Reply, Geol. Soc. Am. Bull., 84, 3127-3130, doi:10.1130/0016-7606(1973)84<3127:ROTROM>2.0.CO;2.

Navarro Hervas, F. (1991), El Sistema Hidrografico del Guadalentin, Consejeria de Política Territorial, Obras Públicas, Murcia, Spain.

Neukum, G., and R. Jaumann (2004), HRSC: The high resolution stereo camera of Mars express, Eur. Space Agency Spec. Publ., ESA SP, 1240 pp. $17-35$.

Pieri, D. C. (1980), Martian valleys: Morphology, distribution, age, and origin, Science, 210(4472), 895-897, doi:10.1126/science.210.4472.895.

Quantin, C., P. Allemand, N. Mangold, G. Dromart, and C. Delacourt (2005) Fluvial and lacustrine activity on layered deposits in Melas Chasma, Valles Marineris, Mars, J. Geophys. Res., 110(E12), E12S19, doi:10.1029/ 2005JE002440.

Reid, I., and L. Frostick (1994), Fluvial sediment transport and deposition, in Sediment Transport and Depositional Processes, edited by K. Pye, pp. 89-156, Blackwell Sci., Oxford, U. K.

Sagan, C., O. B. Toon, and P. J. Gierasch (1973), Climatic change on Mars, Science, 181(4104), 1045-1049, doi:10.1126/science.181.4104.1045.

Salisbury, N. E., J. C. Knox, and R. A. Stephensen (1968), The Valleys of Iowa I: Valley Width and Stream Discharge Relationships in the Major Streams, Univ, of Iowa, Iowa City.

Schumm, S. A. (1974), Structural origin of large Martian channels, Icarus, 22(3), 371-384, doi:10.1016/0019-1035(74)90184-5.

Segura, T. L., O. B. Toon, A. Colaprete, and K. Zahnle (2002), Environmental effects of large impacts on Mars, Science, 298(5600), 1977-1980, doi: $10.1126 /$ science. 1073586

Sharp, R. P., and M. C. Malin (1975), Channels on Mars, Geol. Soc. Am Bull., 86, 593-609, doi:10.1130/0016-7606(1975)86<593:COM>2.0. $\mathrm{CO} ; 2$.

Sinha, S. K., and G. Parker (1996), Causes of concavity in longitudinal profiles of rivers, Water Resour. Res., 32(5), 1417-1428, doi:10.1029/ 95WR03819.

Skinner, J. A., T. M. Hare, and K. L. Tanaka (2006), Digital renovation of the atlas of mars 1:15000000-scale global geologic series map, Lunar Planet. Sci., XXXVII, Abstract 2331. 
Smith, D. E., G. A. Neumann, R. Arvidson, E. Guiness, and S. Slavney (2003), Mars Global Surveyor Laser Altimeter Mission Experiment Gridded Data Record (MGS-M-MOLA), 5-MEGDR-L3-V1.0, NASA Distributed Active Archive Cent. for Planet. Data Syst. (PDS), Greenbelt, Md.

Snyder, N. P., and L. L. Kammer (2008), Dynamic adjustments in channel width in response to a forced diversion: Gower Gulch, Death Valley National Park, Calif. Geol., 36(2), 187-190.

Som, S. M., D. R. Montgomery, and H. M. Greenberg (2008), The Mars Orbiter Laser Altimeter dataset: Limitations and improvements, Mars, 4 , $14-26$.

Squyres, S. W., and A. H. Knoll (2005), Sedimentary rocks at Meridiani Planum: Origin, diagetiesis, and implications for life on Mars, Earth Planet. Sci. Lett., 240(1), 1-10, doi:10.1016/j.epsl.2005.09.038.

Squyres, S. W., et al. (2004), In situ evidence for an ancient aqueous environment at Meridiani Planum, Mars, Science, 306(5702), 17091714, doi:10.1126/science. 1104559.

Stepinski, T. F., and A. P. Stepinski (2005), Morphology of drainage basins as an indicator of climate on early Mars, J. Geophys. Res., 110(E12), E12S12, doi:10.1029/2005JE002448.

Stepinski, T. F., M. L. Collier, P. J. McGovern, and S. M. Clifford (2004), Martian geomorphology from fractal analysis of drainage networks, J. Geophys. Res., 109(E2), E02005, doi:10.1029/2003JE002098.

Thomas, S. G. (Ed.) (1997), Arid Zone Geomorphology, John Wiley, New York.

Whipple, K. X. (2004), Bedrock rivers and the geomorphology of active orogens, Annu. Rev. Earth Planet. Sci., 32, 151-185, doi:10.1146/annurev. earth.32.101802.120356.

Whipple, K. X., and G. E. Tucker (1999), Dynamics of the stream-power river incision model: Implications for height limits of mountain ranges, landscape response timescales, and research needs, J. Geophys. Res., 104(B8), 17,661-17,674, doi:10.1029/1999JB900120
Wilhelms, D. E., and R. J. Baldwin (1989), The role of igneous sills in shaping the Martian uplands, Proc. Lunar Planet. Sci. Conf., 19th, $355-$ 365 .

Williams, G. P. (1978), Bank-full discharge of rivers, Water Resour. Res., 14(6), 1141-1154, doi:10.1029/WR014i006p01141.

Williams, R. M. E., and R. J. Phillips (2001), Morphometric measurements of Martian valley networks from Mars Orbiter Laser Altimeter (MOLA) data, J. Geophys. Res., 106(E10), 23,737-23,751, doi:10.1029/ 2000JE001409.

Wilson, L., and P. J. Mouginis-Mark (2003), Phreatomagmatic explosive origin of Hrad Vallis, Mars, J. Geophys. Res., 108(E8), 5082, doi:10.1029/2002JE001927.

Wilson, L., G. J. Ghatan, J. W. Head, and K. L. Mitchell (2004), Mars outflow channels: A reappraisal of the estimation of water flow velocities from water depths, regional slopes, and channel floor properties, J. Geophys. Res., 109(E9), E09003, doi:10.1029/2004JE002281.

Wolman, M., and R. Gerson (1978), Relative scales of time and effectiveness of climate in watershed geomorphology, Earth Surf. Processes Landforms, 3, 189-208.

Wolman, M. G., and J. P. Miller (1960), Magnitude and frequency of forces in geomorphic processes, J. Geol., 68(1), 54-74.

Zuber, M. T., D. E. Smith, S. C. Solomon, D. O. Muhleman, J. W. Head, J. B. Garvin, J. B. Abshire, and J. L. Bufton (1992), The Mars Observer Laser Altimeter investigation, J. Geophys. Res., 97(E5), 7781-7797.

H. M. Greenberg, D. R. Montgomery, and S. M. Som, Quaternary Research Center and Astrobiology Program, Department of Earth and Space Sciences, University of Washington, Seattle, WA 98195, USA. (sanjoy@u.washington.edu) 